\title{
Çevre ve Dış Politika İlişkisi: Çernobil Kazası ve Türk Dış Politikasına Yansıması*
}

\author{
Nermin KILIÇ**
}

Öz

26 Nisan 1986'da Çernobil nükleer enerji santralinde meydana gelen kaza sonucunda oluşan nükleer serpinti, aralarında Türkiye'nin de bulunduğu pek çok ülkeyi etkilemiştir. Sonuçları itibariyle çevresel problemlerin sınır aşan niteliğini gösteren bir örnek olan Çernobil kazası, ağırlıklı olarak insan sağlığı ve çevreyle ilgili problemlere yol açmıștır. Ekonomik ve dış politikaya dair yansımalarıyla birlikte uluslararası bir sorun halini alan bu kaza, kısa sürede siyasi bir krize dönüşmüștür. Kazanın öğrenilmesinden sonra etki altında kalan ülkelerin birbirinden farklı acil durum ve kriz yönetimi süreçleri söz konusu olmuştur. Bu makale, söz konusu krizde Türkiye'nin tutumunu, acil durum ve kriz yönetim süreçlerini ve kazanın Türk dış politikasına yansımalarını analiz etmektedir

Anahtar Kelimeler: Çernobil, Nükleer Kaza, Acil Durum Yönetimi, Kriz Yönetimi, Türk Dış Politikası.

\section{Environment and Foreign Policy Relations: Chernobyl Accident and Its Reflections on Turkish Foreign Policy}

\begin{abstract}
Many countries including Turkey were affected by the nuclear accident that took place at the the Chernobyl nuclear power plant on April 26, 1986. Regarding its consequences, Chernobyl accident, which was an example of the transboundary nature of environmental problems, have mainly caused human health and environmental problems. This accident, which became an international problem with its economic and foreign policy reflections, soon turned into a political crisis. After learning the accident, the affected countries went through different emergency and

\footnotetext{
Özgün Araştırma Makalesi (Original Research Article)

Geliş Tarihi: 27.06.2016 Kabul Tarihi: 05.08.2016

DOI: http://dx.doi.org/10.17336/igusbd.305639

${ }^{*}$ Bu makale TUBITAK 1001 Projesi (Proj. No: 112K172) desteğiyle üretilmiștir.

** Doktora Öğrencisi, Yıldız Teknik Üniversitesi, Siyaset Bilimi ve Uluslararası İlişkiler Anabilim Dalı, İstanbul, Türkiye, E-posta: nerminklc@gmail.com
} 
crisis management processes. This article analizes Turkey's attitude, emergency and crisis management processes, and the reflections of this accident on Turkish foreign policy.

Sayfa/Page | 152

İGÜ Sos. Bil. Derg., 4 (1), 2017, ss. $151-179$

Keywords: Chernobyl, Nuclear Accident, Emergency Management, Crisis Management, Turkish Foreign Policy.

\section{Giriş}

Çernobil nükleer enerji santralinde meydana gelen kaza, etkilediği geniş alan ve sebep olduğu zararlar bakımından nükleer enerjinin barışçıl kullanımı tarihindeki en büyük kaza olarak tanımlanmaktadır. ${ }^{1}$ Çernobil örneğinde kazanın yarattığı çevresel kirliliğin yanında söz konusu edilmesi gereken diğer bir unsur da nükleer enerji santrali kazalarının diğer ülkelere etkileri, alınan önlemler ve uluslararası ilişkiler boyutudur. Çernobil radyoaktif serpinti krizi, yalnızca kamu sağlı̆̆ı ile ilgili bir problem değil, aynı zamanda ekonomik ve dış politikaya dair yansımalarıyla birlikte uluslararası bir sorundur. ${ }^{2}$

26 Nisan 1986'da Ukrayna'nın kuzey bölgesinde bulunan Çernobil nükleer enerji santralinde meydana gelen kaza ve bu kazanın sonucu olan nükleer serpinti aralarında Türkiye'nin de bulunduğu pek çok ülkeyi etkilemiştir. Sovyet Sosyalist Cumhuriyetler Birliği (SSCB) ilk günlerde kazaya dair hiçbir açılama yapmamıștır. Kazadan sonraki iki gün içerisinde radyasyon düzeylerinde tespit edilen artış sonucunda Çernobil kazasından tüm dünya haberdar olmuştur.

Çalışmanın ana konusunu Çernobil kazasının açıklanmasından sonra radyasyon bulutundan etkilenen ülkelerden biri olan Türkiye'nin, SSCB'ye karşı tutumunun nasıl olduğu ve Türk dış politikasında Çernobil krizine yönelik sürecin nasıl işlediği oluşturacaktır. Çevre ve dış politika ilişkisi çerçevesinde bölgesel nitelikte bir çevresel krize yol açan Çernobil kazasının Türk dıș politikasına yansıması iki ana bașlık altında incelenecektir. Önce dönemin genel siyasi durumu, dış politika anlayışı ve SSCB ile ilişkiler, bunun yanında Çernobil kazasının meydana gelişi söz konusu edilecektir. Daha sonra ise Çernobil kazasının etkileri, farklı boyutları, etkilenen ülkelerin tepkileri ve alınan önlemler ele alınacaktır. Ayrıca Türkiye'deki Çernobil kazası sonrasındaki acil durum ve kriz yönetimi süreçleri ele alınacaktır. Bu bağlamda başlangıçta acil durum yönetimini gerektiren sürecin nasıl bir dıș [ekonomik] politika krizine dönüştüğü tartışllacaktır.

1 Vladimir M. Chernousenko, Chernobyl: Insight from the Inside, çev. John G. Hine, Springer-Verlag Berlin Heidelberg, 1991, s. 1.

${ }^{2}$ Eric K. Stern, Crisis Decisionmaking: A Cognitive Institutional Approach, Stockholm, Swedish National Defence College, 2003, s. 127. 


\section{ÇEVRE ve DIŞ POLİTiKA İLIŞKISİ}

Bazı çevre sorunları ulus-aşırı etkilere sahiptir. ${ }^{3}$ Sonuçları bakımından "çevre felaketi" olarak adlandırılan Çernobil kazası sonucu oluşan radyoaktif bulutun rüzgâr arayıcıllğıyla başka ülkelere taşınmasıyla birlikte, kazanın bu ülkelerde yarattığı kirliliğin yol açtığı sorunlar ve söz konusu sorunlara çözüm arayışları, çevre-dış politika ilişkisinin bir örneğini oluşturmaktadır. Çernobil kazası büyük çapta nükleer kirliliğe sebep olan ilk ve şimdiye kadarki en büyük nükleer reaktör kazasıdır. ${ }^{4}$ Reaktörlerden birinde patlama olmuş ve nükleer bulut rüzgâr aracılığıyla Avrupa'nın büyük bölümüne yayılmıştır. ${ }^{5}$ Çernobil kazası sonrasında radyoaktif kirliliğin atmosfere yayılımı çevre ülkelerde yaşam alanlarında değişik ölçülerde kirlenmeye neden olmuştur. ${ }^{6}$

Çernobil kazası sonucunda oluşan çevresel kirlilik gibi sorunların çözümü ulusal çabayı gerektirdiği kadar; ikili, bölgesel ve çok-taraflı düzeyde uluslararası işbirliğini ve aktif katılımını gerekli kılmaktadır. Nitekim 1972 yılındaki "Stockholm Konferansı"ndan sonra çevre ve ekonomik gelişme arasındaki çatışmaların çözümüne ilişkin uluslararası çabalar artarak sürmüștür. Çernobil nükleer enerji santralinde meydana gelen kazanın yol açtığı çevresel kriz ulusal düzeyde acil durum yönetimini gerektirmiştir. Çernobil kazası sonrasında kaza yerinin ve radyoaktif kirliliğin nereden kaynaklandığının tespiti sürecinden başlayarak ülkelerin ortak çabaları söz konusu olmuştur.

Türkiye, karmaşık bir nitelik gösteren ve sosyo-ekonomik konularla bağlantılı olarak karşımıza çıkan çevresel sorunların çözümü için farklı düzeylerde pek çok uluslararası sözleşmeye taraf olmuştur. Ayrıca çevre politikası temel dış politika konularından birini oluşturmaktadır. ${ }^{7}$ Burada çalışmanın ana sorunsalı olan Çernobil nükleer santral kazasının Türk dış

3 İbrahim Mazlum, "Küresel Siyaset ve Çevre”, Evren Balta (der.), Küresel Siyasete Giriş: Uluslararası İlişkilerde Kavramlar, Teoriler, Süreçler, İstanbul, İletişim Yayınları, 2014, s. 459.

${ }^{4}$ Steven G. Kaplan, “Compensating Damage Arising From Global Nuclear Accidents. The Chernobyl Situation", Loyala of Los Angales International and Comparative Law Review, Cilt 10, No 1, 1988, http://digitalcommons.lmu.edu/cgi/viewcontent.cgi?arti cle $=1133 \&$ context=ilr (Erişim Tarihi 08 Nisan 2016), s. 241. Chernousenko, a.g.e, s. 44 . ${ }^{5}$ Lena Gustafsson, "Environmental Crisis as Drivers of the State and Use of Swedish Forests", External Drivers Affecting Swedish Forest and Forestry, Future Forest Working Report, 2009, s. 13.

${ }^{6}$ Gamze Varol Saraçoğlu, "Son Yirmi Yılda Çernobil Kazası Sonrası Dünyada Yaşananlar", Çernobil Nükleer Kazası Sonrası Türkiye'de Kanser, Ankara, Türk Tabipleri Birliği Yayınları, 2006, s. 11.

${ }^{7}$ http://www.mfa.gov.tr/uluslararasi-cevre-konulari.tr.mfa (Erişim Tarihi 07 Arallk 2015).

Sayfa/Page | 153

IGU J. Soc. Sci., 4 (1), 2017, pp. 151-179. 
politikasına yansımasını ve bu yansıma biçiminin temellerini açıkladı̆̆ kadarıyla, kazanın yaşandığı dönemde dünyada ve Türkiye'de genel siyasi duruma değinmek gerekmektedir.

Sayfa/Page | 154

İGÜ Sos. Bil. Derg., 4 (1), 2017, ss. $151-179$

\section{İlişkiler}

Çernobil kazası SSCB'nin blok liderlerinden biri olduğu iki kutuplu bir dünyada ve Soğuk Savaş'ın yeniden tırmandığı dönem içerisinde vuku bulmuştur. 1980'lerde Türkiye'de pazar ekonomisine geçilirken, SSCB'de de benzer nitelikteki "perestroyka" ve "glasnost" politikalarının uygulanmasına tanık olunmuştur. ${ }^{8}$ Çernobil kazasının yaşandığı tarihi de kapsayan 1980-90 arası dönemde Türkiye, serbest piyasa ekonomisine geçen bir ülke olarak ticaret yaptığı ülkelerin sayısını arttırmıştır. Bu ülkeler içerisinde öne çıkanlardan biri de SSCB olmuştur. Bu dönemde Türkiye ve SSCB arasındaki ikili ilişkilere bakıldığında, ekonomik anlamda işbirliklerine gidildiği ve bunun siyasal alanda da ilişkileri pekiştiren etkileri olduğu görülmektedir. Türkiye ve SSCB arasındaki ilişkiler 1960'ların ortalarından itibaren ekonomik temelde iyileșmiş, bu durum siyasal alana da yansımıștır. SSCB'nin “ideoloji”den uzaklaştığı ve ekonomik alanda yeniden yapılanma çabaları içerisinde olduğu bu dönemde Türkiye'de ekonomik alanda bir yeniden yapılanma sürecindedir. ${ }^{9}$

$\mathrm{Bu}$ dönemde Türkiye ve SSCB arasında kimi zaman siyasal ilișkilerde durgunluk yaşansa da ekonomik ilişkilerin kesintisiz şekilde sürdüğü görülmektedir. 1981 yılında Türkiye'nin SSCB'ye ihracatı 1924'den sonraki en üst düzeye çlkmış, benzer şekilde 1983'de gerçekleştirilen ithalat da 1924'den sonraki en üst düzeyde olmuştur. Buna ek olarak birinci ve ikinci Özal hükümetinin programında SSCB'yle ilişkilerin özellikle ekonomik alanda geliştirileceğinin vurgulandığı görülmektedir.10 Dönemin dış politikasında öncelikle serbest piyasa ekonomisine geçişin gerekleri üzerinde yoğunlaşan bir anlayış göze çarpmaktadır. 12 Eylül 1980 askeri darbesi sonrası ilk seçim olan 6 Kasım 1983'de Turgut Özal'ın kurduğu Anavatan Partisi iktidar olmuştur. Özal dönemi, dış politikanın yapılışına getirdiği farklılıklar açısından

${ }^{8}$ Erel Tellal, "SSCB'yle İlișkiler", Baskın Oran (ed.), Türk Dıș Politikası: Kurtuluş Savaşından Bugüne Olgular, Belgeler, Yorumlar, c. 2, 4. bs, İstanbul, İletişim Yayınları, 2002, s. 166.

9 a.g.e, s. 163.

10 a.g.e, s. 161-165. Bu amaçla ilgili olarak attlan adımlardan biri, 18 Eylül 1984'de imzalanan Doğal Gaz Anlaşması'dır. Doğal Gaz Anlaşması Türkiye-SSCB ikili ilișkilerinde bir dönüm noktası olmuştur. Bu anlaşma müteahhitlik hizmetleri ve ticari işbirliği konusunda yeni olanaklar yaratmıştır. Türkiye 1987'den itibaren 25 yıl boyunca serbest döviz karşıllı̆ında SSCB'den doğal gaz almayı kabul ederken, SSCB de bu satıştan elde ettiği gelirin yüzde 70'ini Türkiye'den mal ithal ederek kullanmayı kabul etmiş̦tir. A.g.e, s. 163. 
bir kırılma noktası oluşturur. 0 zamana kadar Türk dış politikası diplomatik, askeri, siyasi konular ekseninde yürütülüyorken ve ekonominin belirgin bir ağırlığı yokken, Özal ekonomik dış politikaya ağırlık vermiştir.11

\section{Çernobil Kazası}

SSCB'nin Ukrayna bölgesinin Kiev kentine 130 km mesafede kurulan Çernobil Nükleer Enerji Santrali'nin inşasına 1970 yılında başlanmıştır. İlk reaktör 1977'de, diğer üç reaktör ise 1978, 1981 ve 1983 yıllarında tamamlanmıștır. ${ }^{12}$ Çernobil kazası "hatalı bir dizaynın, yasal olmayan bir operasyonun ve izinsiz bir deneyin ${ }^{13}$ ölümcül kombinasyonuyla"14 26 Nisan 1986'da saat 01.24 'de meydana gelmiștir. ${ }^{15}$

Çernobil Nükleer Enerji Santrali'nde üst üste iki patlama olmuştur. ${ }^{16}$ Gerçekleşen patlamalar ile santralin bin ton ağırlığındaki çatısı önce gökyüzüne fırlamış ardında da santralin üzerine düşmüştür. ${ }^{17} \mathrm{Bu}$ kaza sonucunda reaktör kalbinin tamamı, binanın da büyük bir kısmı hasar görmüştür. Kaza sonrasında çıkan yangın ancak 9 Mayıs 1986'da söndürülebilmiştir. ${ }^{18}$ Yangının söndürülmesi sürecinde SSCB, İsveç ve Federal

11 Özal dönemi Türkiye'nin dıș politikasına dair ayrıntılı bir inceleme için bkz. Gülistan Gürbey, Arızalı Demokrasilerde Dış Politika: 1983-1993 Özal Döneminde Türkiye'de Toplumsal Talepler ve Karar Süreçleri, Ankara, ODTÜ Yayıncılık, 2010, s. 74-90. Gülistan Gürbey, “Özal'ın Dış Politika Anlayıșı”, İhsan Sezal, İhsan Dağı (ed.), Kim Bu Özal? Siyaset, İktisat, Zihniyet, 2.bs, İstanbul, Boyut Yayıncılık, 2003, s. 285-306. Özal dönemi ve biyografisi için bkz. Hikmet Özdemir, Turgut Özal: Biyografi, İstanbul, Doğan Kitap, 2014. M. Ali Birand, Soner Yalçın, The Özal: Bir Davanın Öyküsü, İstanbul, Doğan Kitap, 2001.

12 Wil Mara, The Chernobyl Disaster: Legacy and Impact on the Future of Nuclear Energy, Newyork, Marshall Cavendish, 2011, s. 34.

${ }^{13}$ Çernobil kazasının uluslararası kurallara göre yapılmasına izin verilmeyen bir deney yapılması sonucunda meydana geldiği belirtilmektedir. Hamit Palabıyık, Hikmet Yavaş ve Murat Aydın, Türkiye'de Nükleer Santral Kurulabilir mi?: Çatışmadan Uzlaşıya Nükleer Enerji ve Sosyal Kabul, Ankara: Uluslararası Stratejik Araştırmalar Kurumu, 2010, s. 186. Chernousenko, kazaya neyin sebep olduğuna dair farklı yorumların olduğunu ifade etmektedir. Sovyetlerin çalışan hatası olarak ifade edilebilecek olan hükmünün tersine, İngiliz uzmanlar dizayn hatasının felakete sebep olduğunu söylemektedir. Chernousenko, a.g.e, s. 74. Türkiye Atom Enerjisi Kurumu, "Çernobil Nükleer Santralinin Özellikleri ve Kazanın Oluşumu", Çernobil Serisi, no. 4, 2. bs, Ankara, 2007, s. 9.

14 Varol Saraçoğlu, a.g.e, s. 18.

15 Mara, a.g.e, 94.

${ }^{16}$ Stern, a.g.e, s. 220.

${ }^{17}$ Alpaslan Türkkan, “Çernobil Nükleer Santral Kazasının Türkiye’ye Etkisi”, Cernobil Nükleer Kazası Sonrası Türkiye'de Kanser, Ankara: Türk Tabipleri Birliği Yayınları, 2006, s. 46. Nükleer santraller kapalı(batı tipi) ve açık(doğu tipi) olmak üzere iki tip olarak inşa edilmektedir. Batı tipinde reaktör kalpleri kapalı bir beton kubbe içine yapılırken, doğu tipinde ise reaktör kalpleri açık olarak inşa edilmiştir. Palabıyık, Yavaş ve Aydın, a.g.e, s. 182.

18 TAEK, a.g.e, s. 13. 
Sayfa/Page | 156

İGÜ Sos. Bil. Derg., 4 (1), 2017, ss. $151-179$

Almanya'dan yardım talebinde bulunmuștur. ${ }^{19}$ İsveç, Sovyetler'in talebinden santralde yakıt bulunan depoların bir kısmının ya da tamamının eridiğinin anlaşıldığını açılamıştır. ${ }^{20}$ Çernobil kazasından hemen sonra kazanın sebeplerini araştırmak üzere kurulan SSCB hükümet komisyonu21, 1986 yılının Haziran ayında Çernobil'in dördüncü ünitesinin uzun süreli korunmasına dair bir yönetmelik çıkarmıştır. Çernobil için planlanan ve oldukça maliyetli olan yeni korunak binası birçok ülkenin katılımıyla sürmektedir. ${ }^{22}$

\section{ÇERNOBILL KAZASININ ETKILLERI}

Nükleer reaktör kazası, bir reaktörün içindeki radyoaktivitenin bir bölümünün çevreye yayılması anlamına gelmektedir. ${ }^{23}$ Çernobil kazası sonrasında açığa çıkan radyoaktif maddeler 1200 metreyi aşan yüksekliğe çıkmış ve oluşturduğu radyoaktif bulutlar ile atmosfere yayılmıştır. Yayılan radyasyonun yüzde 25 'i ilk anda yakın çevreyi etkilemiştir. ${ }^{24}$ İlk etapta santrale $4 \mathrm{~km}$ mesafede bulunan Pripyat kasabasından ve Çernobil'den gelen itfaiye ekipleri ve santral çalışanları çok yüksek düzeyde radyasyona maruz kalmıștır. ${ }^{25}$ Radyoaktif tozun hemen hemen yarısı 30 km'lik çapa sahip alanı (bu alan aynı zamanda en çok kirlenmenin olduğu bölgedir ${ }^{26}$ ), geriye kalanı ise bulutlarla birlikte dünya çevresinde dolaşarak yağmur şeklinde suya ve toprağa karışarak çok daha geniş bir alanı kirletmiştir. ${ }^{27}$ Nükleer serpinti yalnızca kazanın yaşandığı bölgeyi değil, radyoaktif bulutun rüzgârla taşınmasıyla çok uzak bölgeleri de kirletmiștir. ${ }^{28}$

${ }^{19} \mathrm{http}: / /$ ayintarihi.byegm.gov.tr/WaVeZ/date/1986-04-29 (Erişim Tarihi 13 Aralık 2015).

${ }^{20} \mathrm{http}: / /$ www.gecmisgazete.com/haber/tepemizde-olum-bulutu-dolasiyor (Erișim Tarihi 13 Aralık 2015).

${ }^{21}$ Celestine Bohlen, "Soviet Secrecy in the Face of Calamity", David Erik Nelson (ed.) Perspectives on Modern World History: Chernobyl, Farmington Hills, Greenhaven Press, 2009, s. 38.

22 TAEK, a.g.e, s. 18-22. On binlerce ișçi tarafından 206 gün içinde yaklașık $400000 \mathrm{~m}^{3}$ beton ve 7000 ton metal malzeme kullanılarak bir koruma binası(lahit) inșa edilmiştir. Çernobil kazasının etkilerinden korunmak amacıyla uluslararası düzeyde çabalar hala devam etmektedir.

${ }_{23}$ Pelin Özcan Kara ve Emel Ceylan Günay, "Çernobil Kazası ve Etkileri”, M. Ü. Tip Fakültesi Lokman Hekim Tıp Tarihi ve Folklorik Tıp Dergisi, cilt 3, no 2, 2013, s. 32. ${ }^{24}$ Pripyat șehri 1970 yılında Çernobil nükleer santrali çalışanları ve aileleri için kurulmuştur. Mara, a.g.e, s. 34 .

25 Özcan Kara, Günay, a.g.m, s. 33.

26 Türkiye Atom Enerjisi Kurumu, "Çernobil Kazasının Ülkeler Üzerindeki Etkileri”, Çernobil Serisi, no. 5, 2. bs, Ankara, 2007, s. 5.

27 Türkkan, a.g.m, s. 46.

${ }^{28}$ Stern, a.g.e, s. 220. Bu konuda bkz.; Julia A. Schwartz, "International Nuclear Third Party Liability Law: The Response to Chernobyl", International Nuclear Law in the Post-Chernobyl Period, OECD Nuclear Energy Agency, 2006, s. 37, https://www.oecdnea.org/law/chernobyl/SCHWARTZ.pdf (Erişim Tarihi 04 Nisan 2016). 


\section{Kazanın Duyulması, Uluslararası Etkileri ve Tepkiler}

Soğuk Savaş ortamında SSCB kazayı ilk etapta saklamaya çalışmıştır. Çernobil kazası Sovyet yönetimi tarafından İsveç'ten gelen kaza anonsuna kadar gizli tutulmuştur. Öyle ki, Belarus'un bir kasabasında yetkililer sığır sürülerinin tahliye edilmesine karşıllk kazayla ilgili olarak hiçbir şey söylememiştir. ${ }^{29}$ Yani yalnızca diğer ülkeler değil, kendi vatandaşları da kaza hakkında bilgilendirilmemiştir. SSCB vatandaşları kazayı ancak 7 Mayıs 1986'da öğrenebilmiştir. ${ }^{30}$ Kiev'de ilk defa yerel bir gazete 3 Mayıs 1986'da nükleer santralde yangın çıktığı bilgisini vermiştir. ${ }^{31}$

Daha öncede belirtildiği gibi kazayı dünyaya duyuran haber İsveç’ten gelmiștir. ${ }^{22} 28$ Nisan 1986 saat 07.00'de Stockholm'ün 120 km kuzeyinde bulunan Forsmark Nükleer Santrali'nde tesis dışında çalışan personelin rutin radyasyon denetimi sırasında iş kıyafetlerinde (özellikle ayakkabılarında yüksek düzeyde) tespit edilen anormal düzey üzerine İsveçli yetkililer bunun İsveç'te bulunan başka bir santraldeki bir sızıntıdan kaynaklanabileceği konusunda endișelenmiştir. ${ }^{33}$ Araştırma sonunda böyle bir durumun olmadığ anlaşılınca, İsveç üzerindeki hava akımının kökenini bulmak için meteoroloji raporları incelenmiştir. Yapılan incelemeler sonucunda radyasyonun SSCB'nin

Nükleer serpintinin çevresel etkileri özellikle tarımsal ürünlerin radyoaktif kirliliğe maruz kalmasından dolayı, kazadan etkilenen ülkelerde ekonomik kayıplara neden olmuştur. Kaza sonrasında nüfusu 14.000 olan Çernobil şehri büyük oranda, nüfusu 49.400 olan Pripyat ise 27 Nisan 1986'da tamamen terk edilmiştir. Ayrıca 30 km'lik yasak bölge oluşturulmuştur. Bkz.; Ekonomi ve Dış Politika Araştırmalar Merkezi, Sinan Ülgen (ed.), Nükleer Enerjiye Geçişte Türkiye Modeli, İstanbul, 2011, s. 58. Kazanın boyutlarını en iyi Birleşmiş Milletler İnsani Yardım Koordinasyon Ofisi'nin bildirdiği belirtilmektedir. Ofis; Rusya, Ukrayna ve Belarus'da yaklaşık 8.4 milyon insanın radyasyona maruz kaldığını, yaklaşık $150.000 \mathrm{~km}^{2}$ lik alanın kirlendiğini, yaklaşı $52.000 \mathrm{~km}^{2}$ 'lik tarımsal alanın harap hale geldiğini ve 400.000 insanın yeniden yerleşime tabi tutulduğunu belirtmiştir. Çernobil kazası sonrasındaki 1 ay boyunca çevreye yayılan radyoaktif kirlilik, o güne kadar patlatılmış olan tüm atom bombalarından, nükleer santraller ve uranyum madenlerinden doğal ya da kaza ile salınan tüm radyasyondan daha fazladır. Çernobil kazasında ortaya çıkan radyasyonun Hiroşima ve Nagazaki'nin atom bombası ile bombalanmasında açığa çıkandan 200 kat daha fazla olduğu belirtilmektedir. Bkz.; Chernousenko, a.g.e., s. 18; Türkkan, a.g.m., s. 52, 45, 46.

29 Varol Saraçoğlu, a.g.m., s. 14.

${ }^{30}$ Ali Çimen, Tarihi Değiştiren Günler, 3. bs, İstanbul, Timaş Yayınları, 2013, s. 219.

${ }^{31}$ Türkkan, a.g.m., s. 47.

32 Radyasyon düzeyindeki artış ilk olarak Finlandiya tarafından tespit edilmesine rağmen yetkililerin tam olarak ne olduğunu doğrulamadan komşu ülkelere radyasyon düzeylerindeki artışı bildirmemelerinden dolayı İsveçli yetkililerin alarmına kadar radyasyon yüksekliğinin nedeni analiz edilmemiştir. Stern, a.g.e., s. 220. İsveç'in başlattığı süreç içerisinde Danimarka, Finlandiya ve Norveç de yüksek radyasyon oranları tespit ettiklerini bildirmiștir. Bohlen, a.g.m., 38.

${ }^{33}$ Stern, a.g.e., s. 130.

Sayfa/Page | 157

IGU J. Soc. Sci., 4 (1), 2017, pp. 151-179. 
Sayfa/Page | 158

İGÜ Sos. Bil. Derg., 4 (1), 2017, ss. $151-179$.

Ukrayna bölgesinden kaynaklandığı tespit edilmiştir. Bunun üzerine İsveç resmen SSCB'den konu hakkında bilgi istemiștir. ${ }^{34}$ Sovyet yetkililer o zamana kadar kazayı hem kendi vatandaşlarından hem de diğer ülkelerden saklarken, İsveç'in bilgi talebi üzerine Kiev'in 130 km kuzeyindeki Pripyat ırmağı kıyısında bulunan Çernobil Nükleer Enerji Santrali'nde bir kaza meydana geldiğini açıklamıştır.35 Ancak kazanın boyutları ve nedenleri daha sonra açıklığa kavuşmuştur.
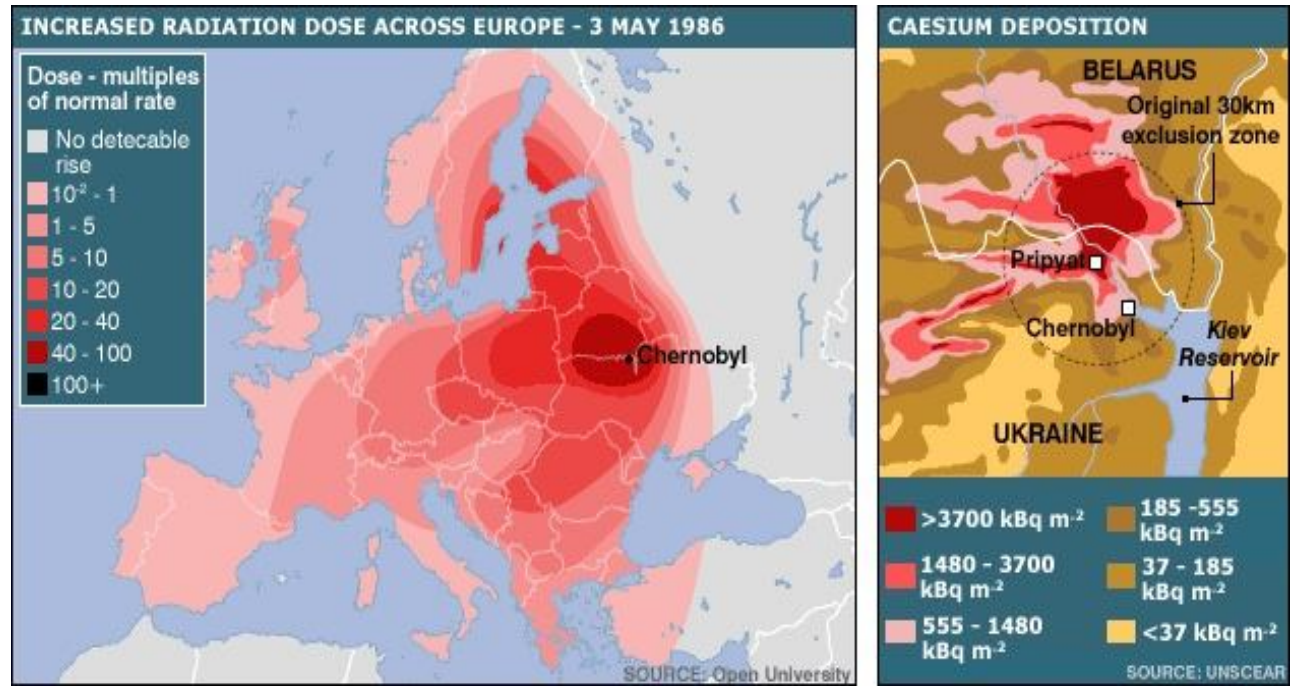

Şekil 1: 3 Mayıs 1986 itibariyle Radyoaktif Serpintinin Etki Alanı ${ }^{36}$

SSCB'nin kaza hakkındaki resmi açıklamasından sonra kaza haberi dünya çapında gazetelerin ilk sayfasında yer almış ve birçok ülkede yoğun çevresel radyasyon ölçüm programları başlatılmıştır. Çernobil nükleer enerji santralindeki kazadan en çok etkilenen ülke SSCB'dir. SSCB dışında meteorolojik koşullar ve kaza yerine uzaklık başta olmak üzere çeşitli faktörlere bağlı olarak Avrupa ülkelerinin hemen hepsi değișik düzeylerde

34 İsveç, Moskova'daki elçiliği aracılığıyla Sovyet dışişleri bakanlığına kazanın nedenleri, boyutları, durum tespiti ve sonuçları hakkında bilgi talebinde bulunmuştur. a.g.e., ss. $228-229$.

${ }^{35}$ Ahmed Yüksel Özemre, Cernobil Komplosu, İstanbul, Bilge Yayıncılık, 2004, s. 20. SSCB kaza hakkındaki resmi açıklamayı 28 Nisan 1986'da yapmıştır. TAEK, a.g.e., s. 27. 28 Nisan 1986'da SSCB'nin resmi haber ajansı TASS (Telegraph Agency of the Soviet Union), Cernobil nükleer santralinde kaza olduğunu, kazanın etkilerini gidermek için gereken önlemlerin alındığını ve kaza kurbanlarına gereken yardımın başlatıldığını bildirmiştir. http://ayintarihi.byegm.gov.tr/WaVeZ/date/1986-04-29 (Erișim Tarihi 13 Aralık 2015). TASS reaktörlerden birinin hasar gördüğünü ve olayı soruşturmak için hükümet komisyonunun kurulduğunu açıklamıştır. Bohlen, a.g.m., s. 37.

${ }^{36} \mathrm{http}: / /$ news.bbc.co.uk/2/shared/spl/hi/guides/456900/456957/html/nn3page1. stm (Erişim Tarihi 12 Mayıs 2016). 
etkilenmiştir. ${ }^{37}$ Kazanın yaşandığı tarihte rüzgârın kuzey-batı yönünde olması nedeniyle İskandinavya, Hollanda, Belçika ve İngiltere'de birikimler görülmüştür. Sonrasında rüzgârın yönünün güneye doğru değişimiyle Avrupa'nın güney ve orta bölgeleri ve Akdeniz'in kuzeyi ve Balkanların bazı bölgelerinde radyoaktif birikim meydana gelmiştir. ${ }^{38}$

Çernobil'den kuzeye doğru esen rüzgârlarla radyoaktif bulut 28 Nisan da İskandinavya'ya ulaşmıștır. ${ }^{39}$ Rüzgâra bağlı olarak seyreden radyasyon bulutları kuzey yarı kürede birçok ülkeyi etkilemiştir. Radyoaktif bulutların Avrupa üzerinden geçişi sırasında yağmur alan Avusturya, Doğu ve Güney İsviçre, Güney Almanya'nın bir bölümü ve İskandinav ülkelerinde kirlenme diğer birçok ülkeye göre çok daha fazla olmuştur. ${ }^{40}$ Kuzey yarı kürede yaşayan insanların çoğu çeşitli düzeylerde radyasyona maruz kalmışlardır. SSCB dışındaki yerlerde halkın radyasyona maruz kalmasının ana kaynağı kirlenmiş gidalar olmuştur. 41

30 Nisan 1986'da Federal Almanya Dışişleri Bakanı Hans Dietrich Genscher'in, Batı Avrupa ülkeleri dişişleri ve savunma bakanlarının iki gün süren toplantısı sonunda yaptığı açıklamada, SSCB'yi kazanın yaşandığı Çernobil santrali türündeki bütün santralleri kapatmaya çağırdığı belirtilmektedir. Ayrıca SSCB'nin facianın nedenleri hakkında bilgi vermesini ve merkezi Viyana'da bulunan Uluslararası Atom Enerjisi Ajansı'nın Çernobil'de incelemeler yapmasına izin vermesi istenmiştir.42 14 Mayıs 1986'da Sovyetler Birliği Komünist Partisi Genel Sekreteri Mihail Gorbaçov Moskova'da yaptığı açıklamada, kazaya Çernobil nükleer santralindeki bakım çalışmaları sırasında meydana gelen ani bir patlamanın neden olduğunu

37 Çernobil kazası Doğu Avrupa ülkelerini de etkilemiştir. AET'in Doğu Avrupa ülkelerinin tarımsal ürünlerini ambargosu, turist trafiğinde azalma, çeşitli nükleer güç istasyonlarının tamamlanmasında gecikmeler, nükleer reaktörlerde güvenlik önlemlerinin arttırılması çabaları Doğu Avrupa ülkelerinde ekonomik kayıplara neden olmuştur. Çernobil kazası ayrıca bu ülkelerin enerji politikalarını da etkilemiştir ancak nükleer enerjiden vazgeçilmemiștir. Çernobil kazasının Doğu Avrupa ülkeleri (Bulgaristan, Çekoslovakya, Estonya, Alman Demokratik Cumhuriyeti, Macaristan, Letonya, Litvanya, Polonya, Romanya ve Yugoslavya) üzerindeki etkileri, kazayı ele alış biçimleri, halkın bilgilendirilmesi ve resmi makamların kazanın etkileri konusunda aldıkları tavırlar konusunda ayrıntılı bilgi için bkz. "Chernobyl and Eastern Europe: One Year After the Accident", Radio Free Europe Research, http://osaarchivum.org/files/holdings/300/8/3/pdf/69-7-122.pdf (Erişim Tarihi 01 Nisan 2016).

38 TAEK, a.g.e., s. 6.

39 Özcan Kara, Günay, a.g.m., s. 33.

${ }^{40}$ Radyoaktif bulutun hareketini atmosfer koşulları ve rüzgâr belirlerken, radyoaktif kirlenmeyi belirleyen en önemli etken bulutun geçişi sırasında oluşan yağış̧ır. Bu konuda bkz.; TAEK, a.g.e, s. 6 .

${ }^{41}$ a.g.e., s. 33.

${ }^{42}$ http://ayintarihi.byegm.gov.tr/WaVeZ/date/1986-4-30 (Erişim Tarihi 13 Aralık 2015).

Sayfa/Page | 159

IGU J. Soc. Sci., 4 (1), 2017, pp. 151-179. 
Sayfa/Page | 160

İGÜ Sos. Bil. Derg., 4 (1), 2017, ss. $151-179$

söylemiștir. ${ }^{43}$ Çalıșmanın sınırlılıkları dâhilinde kazadan etkilenen bütün ülkelerin nasıl tepki verdikleri, acil durum ve kriz yönetimini nasıl gerçekleştirdikleri üzerinde ayrıntılı bir şekilde durulmayacaktır. Yalnızca kazayı tespit eden ülke olan ve Çernobil kazasını bir kriz olarak ele alıp acil eylem planı dâhilinde hareket eden İsveç ve İsveç'in verdiği tepkiden farklı olarak kazanın etkilerinin küçük görüldügü ve iyimserliğin hâkim olduğu belirtilen İngiltere örneklerine değinilecektir.

İsveçli yetkililer Çernobil kazası sonrasında Çernobil kaynaklı radyoaktif serpintinin ülkeleri üzerindeki sonuçlarını hem ulusal hem uluslararası boyutlarıyla birlikte bir kriz olarak ele almışlardır. İsveç'in kazaya tepkisi uluslararası çevresel kriz yönetiminin bir örneğini sergilemektedir. Krizin çözümüne yönelik sistemli ve kapsamlı politikalar geliştirilmiştir. Krizin gerektirdiği karar alma sürecinin çoklu, birbirine bağımlı siyasal ve kurumsal alanda gerçekleştiği görülmektedir. ${ }^{44}$ Kriz yönetimi konusundaki karar alma süreçleri aşamalar halinde belirlenip her bir sorunun nasıl ele alınıp çözüleceği ve sorunun çözümüne yönelik hangi adımların atılacağı belirlenmiştir. Ayrıca ulusal ve uluslararası kuruluşlar ve kazadan etkilenen diğer ülkelerle bilgi alışverişlerinde bulunulmuştur. SSCB'yle resmi düzeyde temaslarda bulunulmuş, kazanın boyutları ve kamu sağlığı konusundaki sonuçlarıyla alakalı olarak kazadan sorumlu ülke olan SSCB'den tazminat talebi konusunda tartıșmalar söz konusu olmuștur. 45

İngiltere'de denizaşırı bir nükleer kazaya karşı hazırlıklı olunmadığı ve acil eylem planının bulunmadığı görülmüştür. 466 Mayıs 1986'da İngiltere parlamentosunda Çevre Bakanlığı sekreteri "bu bulutun etkileri önceden kestirilmiştir ve Birleşik Krallık halkının sağlığına etkisi yoktur” demiştir. 13 Mayıs 1986'da yine aynı yetkili "bu süreçte Çernobil kaynaklı ek bir bozukluk yaşanmamıştır. Olay hafta sonu itibariyle bu ülke için bitmiş olacak gibi durmaktadır" demiştir.47 Dolayısıyla İngiltere'de kaza sonrası günlerde yetkililer nezdinde bir iyimserliğin hâkim olduğu görülmektedir. Ancak sonraki günlerde daha yüksek kesimlerdeki alanlarda radyasyon düzeylerinin arttığı tespiti üzerine hükümet çeşitli önlemler almıştır. Küçükbaş hayvan eti tüketimi yasaklanmış, halka yağmur sularının tüketilmemesi tavsiye

${ }^{43} \mathrm{http}$ ://ayintarihi.byegm.gov.tr/turkce/date/1986-05-18 (Erișim Tarihi 13 Arallk 2015). Gorbaçov, Sovyet halkına hitaben yaptığı 24 dakikalık TV konuşmasında nükleer güvenlik ve Çernobil kazasına dair bilgi vermiştir. Gorbaçov ayrıca, nükleer güvenlik konusunda uluslararası işbirliği rejiminin oluşturulması çağrısında bulunmuș ve SSCB'nin bu konuyla ilgili girișimleri desteklemeye hazır olduğunu söylemiştir. Çernobil kazasına Batı'nın verdiği tepkiyi eleştirmiş ve ahlak dışı ve antisovyetizm olarak nitelendirmiştir. Stern, a.g.e., s. 249.

44 a.g.e., s. 219.

45 a.g.e, s. $123-154$.

46 Varol Saraçoğlu, a.g.m., s. 14.

47 a.g.m., s. 14. 
edilmiştir. Pek çok Avrupa ülkesi kamu sağlığını korumak adına önlem olarak inek sütüne göre daha fazla etkilenmiş olan koyun sütünün tüketimini yasaklamıştır.48 Kazadan iki hafta sonra İngiltere'nin Galler bölgesinde tespit edilen radyoaktif kirlilik nedeniyle yeşil alanlar hayvanların girmesine engel olmak amacıyla dikenli tellerle çevrilmiștir. ${ }^{49}$

Sonuç olarak birçok ülkede hâkim olan kaza sonrası şaşkınlık ve buna eşlik eden sessizlik döneminden sonra geniş kamu önlemleri alınması gerekliliği ortaya çıkmıştır. Tarihin en büyük nükleer kazası olarak Çernobil, bu boyuttaki bir kazaya hazırlıklı olunmaması, kazanın erken safhalarında kazaya dair bilgilerin azlığı gibi nedenlerle ${ }^{50}$ kazadan etkilenen ülkelerin önlem almakla görevli yetkili otoriteleri üzerinde önemli ölçüde baskı yapmıştır.51 Çernobil kazasından etkilenen ülkelerde yaşanan durum, etkilenme alanları ve sonuçları kısaca şu şekilde özetlenebilir ${ }^{52}$ :

- Çevre ve gıda maddelerinin kirlenmesi: Radyoaktif serpinti çevre ve gıda maddelerinin kirlenmesine neden olmuştur.

- Sağlık ve sosyal kriz: Radyasyon kaynaklı sağlık sorunları, psikolojik etkiler ve sosyal aksaklıklar sağlık ve sosyal krizlere neden olmuştur.

- Ekonomik gelişimin engellenmesi: Radyoaktif serpintiden etkilenen bölgelerin varlığı tarımda sınırlı alanlara çekilmeye neden olmuş ve tarımsal ürünlerin radyasyonlu olması endişesinin getirdiği olumsuz imaj ekonomik sorunlara yol açmıştır.

\section{ACIL DURUM, KRİ YÖNETIMİ SÜREÇLERİ ve DIŞ POLİTIKA AÇISINDAN TÜRKIYE'NIN TEPKISİ}

Kaza sonrasında Türkiye'nin üç farklı düzlemde faaliyetlerini yürüttüğü görülmektedir; yaşamsal öneme sahip tehditleri ortadan kaldırmaya dönük acil durumu kontrol altına almak, çıkar ve öncelikleri tehdit eden konularda siyasa oluşturmak, uluslararası ilişkilerinde güvenlik, çıkar ve önceliklerini korumak için işbirliği yapmak. Aşağıda bu süreçler ele alınacaktır.

Türkiye Çernobil kazasından 3 gün sonra televizyon aracılığıyla haberdar olmuştur. ${ }^{53} 30$ Nisan 1986'da Hürriyet Gazetesi'nin manşetinde yer

\footnotetext{
48 a.g.m., s. 15.

49 Türkkan, a.g.m., s. 54.

${ }^{50}$ Harry Otway, “The Media and Crisis Manegement”, Boris Segerstahl(ed.), Chernobyl: A Policy Respond Study, Laxenburg, International Institute for Applied Systems Analysis, 1991, s. 134.

51 TAEK, a.g.e.

52 Varol Saraçoğlu, a.g.m., s. 34.

53 Özemre, 29 Nisan 1986 Salı akşamı son TV haberlerinde Kiev yakınlarında bulunan Çernobil nükleer santralinin 4 numaralı reaktör ünitesinde üç gün önce büyük bir nükleer kaza meydana gelmiş olduğunu öğrendiğini belirtmektedir. Özemre, a.g.e., s. 15-16.
}

Sayfa/Page | 161

IGU J. Soc. Sci., 4 (1), 2017, pp. 151-179. 
Sayfa/Page | 162

İGÜ Sos. Bil. Derg., 4 (1), 2017, ss. $151-179$

alan "Tepemizde Ölüm Bulutu Dolaşıyor NÜKLEER ALARM" başlıklı haberde, Çernobil nükleer santralinde meydana gelen kazanın ilk açılklamalarda radyasyon sızıntısı olarak yansıtıldığı ancak santralde patlama olduğunun kesinleştiği bilgisi verilmiştir. Aynı haberde olayı zamanında duyurmayan SSCB’nin kınandığı belirtilmektedir. ${ }^{54}$

Kazanın yaşandığı dönemde Türkiye Atom Enerjisi Kurumu (TAEK) Başkanı olan Prof. Dr. Ahmed Yüksel Özemre'ye göre "Kuş uçuşu Edirne’ye 1090 km, İstanbul'a 1130 km ve Ankara'ya da 1250 km kadar uzaklıkta kuzeybatı yönünde vuku bulan bir nükleer kazanın Türkiye'yi etkilememesi mümkün değildi."55 Özemre'ye göre meteorolojik şartlarla ilk önce İskandinavya'ya ulaşmış olan radyasyon bulutu eğer ilk günlerde Türkiye'ye ulaşmış olsaydı, Türkiye Atom Enerjisi Kurumu'nun o günkü altyapısıyla bunun tespit edilmesi mümkün değildi. Özemre ayrıca dönemde Türkiye'nin elinde az sayıda radyasyon ölçer hassas cihaz olduğunu belirtmektedir. Radyasyon ölçer cihazlar yalnızca TAEK'te değil askeri birliklerde de bulunuyordu. Özemre'nin belirttiğine göre askeri birliklere dağıtılmış olan 1050 adet radyakmetre vardı. Bunların Soğuk Savaş dönemi içerisinde muhtemel bir nükleer bomba tehlikesinin ortaya çıkaracağı yüksek radyasyon değerlerini ölçmek üzere tasarlanan ve hemen hemen her birlikte bulunan cihazlar olduğu ifade edilmektedir. Bu bilgiler ışığında çıkarılabilecek sonuç, Türkiye'nin olası bir nükleer kazaya karşı hazırlıklı olmadığıdır. Soğuk Savaş dönemi içerisinde olası bir radyoaktif serpintiye karşı -yalnızca nükleer silah kullanımına karşı oldukça sınırlı sayıdaki radyasyon ölçer cihaza sahip olmanın dışında- bir hazırlığın ve kurumsallaşmanın olmadığı görülmektedir.

Çernobil kazasının meydana geldiği 26 Nisan 1986 tarihinden TBMM'de 17. dönem 3. yasama yılının son birleșimi olan 10 Temmuz 1986'ya kadarki olan tutanaklar incelendiğinde, Çernobil kazasının yalnızca 30 Nisan 1986'daki birleşimde söz konusu edildiği görülmektedir. ${ }^{6} 30$ Nisan 1986'da TAEK başkanı Özemre kazayla ilgili olarak İstanbul'da bir basın toplantısı

${ }^{54}$ http://www.gecmisgazete.com/haber/tepemizde-olum-bulutu-dolasiyor (Erișim Tarihi 13 Aralık 2015). Kazanın Türkiye'yi etkileme boyutlarının bu tarihte henüz gündemde olmadığı görülmektedir. Dolayısıyla Türkiye SSCB'yi kınayan ülkeler arasında değildir. http://fotoanaliz.hurriyet.com.tr/galeridetay/45429/4369/4/25yil-onceki-mansetler (Erişim Tarihi 13 Aralık 2015).

55 Özemre, a.g.e., s. 16.

56 Bu birleşimde Ağrı Milletvekili Paşa Sarıoğlu, "Sovyet Sosyalist Cumhuriyetler Birliği'nin Ukrayna Cumhuriyeti'nde Çernobil Nükleer Santrali'ndeki patlama dolayısıyla meydana gelen nükleer radyasyon" hakkında gündem dışı bir konuşma yapmıştır. Paşa Sarıoğlu konuşmasında patlamanın muhtemel nedenleri, radyasyon yayılması ve etkisi konusunda bilgi vermiş ve kazanın Türkiye ile ilgili sonuçları hakkında henüz resmi bir açıklama yapmayan hükümete çağrıda bulunmuştur. TBMM Tutanak Dergisi, Dönem 17, Toplantı 99, c. 28, (Nisan, 1986): s. 230-232. 
düzenleyerek o ana kadar kazanın Türkiye'ye yansımadığını ve ölçümlere devam edildiğini bildirmiştir. ${ }^{57}$

Türkiye'de ilk kez 30 Nisan 1986'da radyasyon ölçümlerinde yükseklik tespit edilmiştir. ${ }^{58}$ Kazadan bir hafta sonra 3 Mayıs 1986 cumartesi günü radyoaktif bulut Bulgaristan ve Yunanistan üzerinden Trakya Bölgesi'ne ulaşmıştır.59 Radyoaktif serpintiden 4-5 Mayıs'ta Batı Karadeniz, 7-9 Mayıs 1986'da da Doğu Karadeniz bölgesi etkilenmiștir.60 Radyoaktif bulutun geçtiği sırada Doğu Karadeniz'de özellikle fındık, tütün ve çay üretimi yapılan tarım alanlarında yağış olması radyoaktif kirliliği arttırmıştır.61 Karadeniz bölgesine ait doğal radyasyon düzeyleri 8-10 mikro röntgen/saat düzeylerinden, 4-5 Mayıs 1986 günleri 30-50 mikro röntgen/saat düzeylerine ulaştığı belirtilmektedir. En yüksek radyasyon değeri ise 150 mikro röntgen/saat olarak Batı Karadeniz kıyısındaki Karasu bölgesinde ölçülmüştür. ${ }^{22}$ Çernobil kazası üzerinden 10 gün geçtiğinde radyoaktif parçacıkların farklı oranlarda tüm Türkiye'ye yayıldığı belirtilmektedir.63 Radyoaktif serpintinin etkisi bölgeden bölgeye değişmiştir. Yapılan ölçümler sonucunda radyasyondan korunmak için önlemler alınması zorunlu hale gelmiştir. Bunun üzerine bir dizi önlemler alınmıştır. ${ }^{4}$

\section{Acil Durum ve Kriz Yönetimi, Alınan Önlemler}

Kriz, "beklenmedik, ani, ilgili tarafi hemen tepki vermeye zorlayan durum"65 olarak tanımlanmaktadır. Böyle bir durumda süreci algısal düzeyde kriz olarak tanımlayan aktör, bu süreçten daha fazla zarara uğramadan çıkmak adına uygun önlemler ve yöntemler konusunda kararlar almaya ve aldığı önlemleri uygulamaya zorlanır. Bu bağlamda kriz, kritik seçimler yapılmasını gerektirir. Özemre, Türkiye'de Çernobil kazası sonrası yaşanan süreci

\footnotetext{
${ }^{57}$ http://ayintarihi.byegm.gov.tr/turkce/date/1986-04-30 (Erişim Tarihi 13 Aralık 2015).

58 Özemre, a.g.e., s. 22.

${ }^{59}$ Çernobil kazası sonrasında Türkiye'nin radyoaktif serpintiden etkilenme düzeyini belirlemek üzere Devlet Meteoroloji İşleri Genel Müdürlüğü tarafından 1-10 Mayıs 1986 tarihleri için hazırlanan bölgesel yağış bilgilerini gösteren haritalar için bkz. TAEK, a.g.e., s. 12-16.

60 Türkkan, a.g.m., s. 46-50.

61 Özcan Kara, Günay, a.g.m., s. 35.

${ }^{62}$ Türkiye Atom Enerjisi Kurumu, "Sağlık Bakanlı̆̆ı Bilimsel Kurul Raporu ve Üniversite Görüşleri", Çernobil Serisi, no. 2, 2. bs. Ankara, 2007. Radyasyon ölçüm değerleri hakkında ayrıntılı bilgi için bkz. Türkiye Atom Enerjisi Kurumu, "Türkiye’de Çernobil Sonrası Radyasyon ve Radyoaktivite Ölçümleri”, Çernobil Serisi, no. 6, Ankara, 2006.

${ }^{63}$ Türkkan, a.g.m., s. 50.

64 a.g.m., s. 51.

65http://tdpkrizleri.org/index.php?option=com seoglossary\&view=glossaries\&Itemid =188\&catid=1\&lang=tr (Erişim Tarihi 10 Nisan 2016).
}

Sayfa/Page | 163

IGU J. Soc. Sci., 4 (1), 2017, pp. 151-179. 
Sayfa/Page | 164

İGÜ Sos. Bil. Derg., 4 (1), 2017, ss. $151-179$

"Çernobil krizi" olarak nitelendirmektedir.66 Kaza krizi, teknik ve hukuki anlamda "kaza" olarak algılanabilecek bir gelişmeden kaynaklanır.67 Bu tür krizler beklenmeyen, provoke edilmeyen ve tesadüfî olarak bir kaza sonucu ortaya çıkan krizlerdir. ${ }^{68} \mathrm{Bu}$ bağlamda Çernobil krizi niteliksel anlamda bir kaza krizidir, krizin kaynağını Çernobil nükleer santralinde yaşanan kaza oluşturmaktadır. Çernobil kazası sonrasında Türkiye'de acil durum yönetiminden, kriz yönetimi sürecine geçen zamana yayılmış bir kriz yönetimi söz konusudur. Acil durum, toplumda normal hayat ve faaliyetleri kesintiye uğratan ya da durduran, hızlı ve etkili müdahaleyi gerektiren olayların yaşandığı durumsal değişiklikleri ifade etmektedir. Bu bağlamda nükleer kazalar acil durum yönetimini gerektiren durumlardandır. ${ }^{69}$

Kriz yönetimi değerlendirilirken, genellikle kriz evreleri dörde ayrılarak analiz edilmektedir.70 Türkiye'de karar alıcıların Çernobil krizini nasıl algıladıkları, hangi araç ve yöntemleri kullandıklarını gözlemlemek amacıyla kriz yönetim süreci; kriz öncesi evre, kriz tırmanma evresi, kriz yumuşama evresi ve kriz sonrası evre olmak üzere dört evrede incelenecektir.

Çernobil krizi bir kaza sonucunda ve ani olarak ortaya çlktığı için kriz öncesi evre söz konusu değildir. Krizin başlangıcl, 26 Nisan 1986'da meydana gelen Çernobil kazasıdır. Krizin tırmanma evresini Türkiye'de Çernobil kazası sonrasında yürütülen acil durum yönetimi ve kriz yönetimi süreci oluşturmaktadır. Çernobil kazasına Türkiye'nin ilk tepkisi TAEK'in gözetimi altında kurulan kontrol programıdır. Acil durum yönetimi sürecini yürüten ve karar alıcı konumunda olan kurum TAEK'tir. 29 Nisan 1986 akşamında kaza haberi alınır alınmaz teyakkuz durumuna geçildiği71 ve TAEK tarafından radyasyon ölçümlerine başlanıldığı belirtilmektedir. Trakya, Marmara, Karadeniz kıyı şeridi, Ankara ve İstanbul başta olmak üzere ülke çapında başlatılan radyasyon ölçüm programı, TAEK'in Radyasyon Sağlı̆̆ı ve Güvenliği

66 Özemre, a.g.e., s. 28.

${ }^{67}$ http://tdpkrizleri.org/index.php?option=com_k2\&view=item\&id=229:kriz-c-karantaraf-n-niyeti-veya-roluene-goere-tuerkiye-nin-d-s-politika-krizleri\&Itemid=103\& lang=tr (Erişim Tarihi 10 Nisan 2016), http://tdpkrizleri.org/index.php?option=com seoglossary\&view=glossary\&catid=1\&id=17\&Itemid=111\&lang=tr $($ Erişim Tarihi 10 Nisan 2016).

68 Haydar Çakmak, Uluslararası Krizler ve Türk Silahlı Kuvvetleri, Ankara, Platin, 2004, s. 40.

${ }^{69}$ Recep Sait Arpat, Acil Durum ve Kriz Yönetimi: NATO, AB, ABD, Birleşik Krallık Analizleri ve Türkiye Modeli, Ankara, Gece Kitaplığı, 2016, s. 144-147.

${ }^{70}$ Ayrıntılı bilgi için bkz. Michael Brecher, Crisis in World Politics. Theory and Reality, Oxford, Pergamon Press, 1993, s. 25-27.

71 Özemre'nin belirttiği üzere meteorolojik şartların değişmesi halinde radyasyon bulutunun Türkiye'nin neresini, ne ölçüde etkileyeceğini öngörmek mümkün değildi ve bundan dolayı da hızlı bir șekilde önlemler almak ve bir strateji belirlemek gerekiyordu. Bunun üzerine ilgili birimlere gerekli görülen talimatların verildiği belirtilmektedir. Özemre, a.g.e., s. 16-17, 279. 
Dairesi(RSGD), Çekmece Nükleer Araştırma ve Eğitim Merkezi (ÇNAEM) ve Ankara Nükleer Araştırma ve Eğitim Merkezi(ANAEM) tarafından yürütülmüştür.72 Meteorolojik verilerin incelenmesi sonucunda kritik bölgeler olarak değerlendirilen Trakya ve Doğu Karadeniz bölgesine gezici radyasyon ölçüm birimleri gönderilmiştir. TAEK tarafından nükleer serpintinin etkili olduğu bölgelerde yaşayan vatandaşların uymaları gereken önlemler ilan edilmiş ve gezici radyasyon ölçüm birimleri kurulmuştur. İlk olarak 29 Nisan 1986'da Çekmece Nükleer Araştırma ve Eğitim Merkezi'ne bağlı ekipler İstanbul'un Karadeniz kıyılarında havadaki radyasyon miktarını saptamaya yönelik ölçümlere başlamışlardır. ${ }^{73}$

Tehlike durumu TAEK tarafından yönetilmiş, kirlilik olan ya da olması beklenen bölgelerde 24 saat çalışmak üzere ekipler görevlendirilmiştir. TAEK radyasyon bulutu hareketleri hakkında düzenli bilgi almak üzere Devlet Meteoroloji İşleri Genel Müdürlüğü ve "mevcut imkânlarını kullanarak yaptıkları radyasyon ölçüm sonuçlarını TAEK'e bildirmek üzere Genelkurmay Başkanlığı ile koordinasyon sağlanmıștır."74 Sivil Savunma Genel Müdürlüğü'nün imkânlarından da yararlanılmıştır. ${ }^{75}$ Uluslararası ilişkiler de TAEK tarafından yürütülmüştür. ${ }^{76}$ Çernobil kazası meydana geldiğinde bir nükleer kaza durumunda uygulanmak üzere hazırlanmış tehlike durum planı ve organizasyonu bulunmuyordu. Bu nedenle Türkiye'nin radyoaktif kirliliğe maruz kaldığı öğrenildiği günden itibaren, ölçümler ve kirlilik olan bölgelerin tespiti için TAEK'in mevcut elemanları ve teknik donanımı çerçevesinde organizasyonlar yapılmış ve faaliyete geçirilmiştir. TAEK, radyasyon düzeylerindeki artışları tespit edip bir dizi önerilerde bulunmuştur. Buna göre radyasyondan etkilenen bölgelerde yağmur suyunun içilmesi yasaklanmış, büyükbaş hayvanların açık alanlarda otlatılması yasaklanmış, taze süt

72 TAEK, a.g.e.

${ }^{73} \mathrm{http}$ ///ayintarihi.byegm.gov.tr/turkce/date/1986-04-29 (Erişim Tarihi 13 Arallk 2015). Mayıs 1986'dan itibaren TAEK tarafından Türk Silahlı Kuvvetleri'nin de imkanları kullanılarak Türkiye çapında havadaki radyasyon düzeyi ölçümleri günde iki defa yapılmış ve analiz sonuçları TAEK'e bildirilmiştir. Meclis Araştırması Komisyon Raporu, https://www.tbmm.gov.tr/sirasayi/donem19/yil01/ss455.pdf, (Erişim Tarihi 13 Aralı 2015), s. 12.

74 TAEK, no. 5.

75 TAEK, no. 6.

${ }^{76}$ Uluslararası kuruluşlarla ve kazadan etkilenen diğer ülkelerle bilgi alışverişi yapılmıştır. Özemre, a.g.e., s. 288. Kaza sonrasında üyesi olunan Viyana'daki Uluslararası Atom Enerjisi Ajansı(IAEA) ve Paris'teki Ekonomi İşbirliği ve Kalkınma Teşkilatı'nın(OECD) Nükleer Enerji Ajansı ile temasa geçilip ellerindeki bilgilerin rutin olarak TAEK'e ulaştırmaları istenmiştir. a.g.e., s. 23. Uluslararası düzeyde işbirliği içinde olunan başlıca kuruluş Uluslararası Atom Enerjisi Ajansı'dır. Palabıyık, Yavaş ve Aydın, a.g.e, s. 96. Uluslararası Atom Enerjisi Ajansı hakkında ayrıntılı bilgi için bkz. https://www.iaea.org/

Sayfa/Page | 165

IGU J. Soc. Sci., 4 (1), 2017, pp. 151-179. 
Sayfa/Page | 166

İGÜ Sos. Bil. Derg., 4 (1), 2017, Ss. $151-179$.

tüketimi yasaklanmış ve 4000 'den fazla büyükbaş hayvan karantina altına alınmıştır.77

TAEK'in Çernobil kazasıyla ilgili resmi bildirisi 3 Mayıs 1986 gecesi radyo ve televizyondan yayınlanmıştır. ${ }^{78}$ TAEK başkanı Özemre tarafından Türkiye Radyo ve Televizyon Kurumu ve Anadolu Ajansı aracılığıyla alınması gerekli önlemler konusunda kamuoyu açıklaması yapılmıştır. Edirne Valiliği konu hakkında bilgilendirilmiştir. ${ }^{79}$ Bildiriden sonraki günlerde büyükbaş hayvanların karantinasına ilişkin madde hariç bütün tedbirlerin kaldırılmış olduğuna dair ikinci bir duyuru yayınlanmıştır. ${ }^{80}$

TAEK'in yürüttüğü acil durum yönetimi sürecinde radyasyon düzeylerinin halka açlklanmaması ilkesi benimsenmiştir. Özemre, TAEK bünyesinde alınan önlemler arasında radyasyon düzeylerinin halka açıklanmaması ilkesinin bulunduğunu ifade etmektedir.81 Ayrıca Çernobil ile

${ }^{77}$ Enis Özyar, "Effects of Chernobyl Accident on Turkey", http://link.springer.com/ chapter/10.1007\%2F978-94-007-0975-1_13\#page-1 (Erişim Tarihi 24 Kasım 2015). Daha sonraki süreçte TAEK'in önerisi üzerine devletin bunların sahiplerine tazminat ödediği belirtilmektedir. Özemre, a.g.e., s. 288. Dolayısıyla nükleer kazalar nedeniyle doğabilecek tazminat haklarının ödenmesini sağlamak için gerekli ulusal tazminat rejiminin olmadığı görülmektedir.

Radyasyondan etkilendiği tespit edilen bölgelerde süt haricindeki gidalarda Avrupa Ekonomik Topluluğu (AET) limitlerinin aşağısında radyasyon tespit edilmesi sonucu, sütten radyasyona maruz kalma durumunu engellemek amacıyla sütün tüketimi engellenmesi amaçlanmış ve bunlardan peynir yapılması suretiyle radyasyonun tamamen yok olana kadar bekletilmesi yoluna gidilmiştir. Meralardaki hayvanların radyoaktif kirlilikten etkilenmiş olan taze otları yemesini engellemek için ahırda tutulmaları, saman ve suni yem ile beslenmeleri sağlanmaya çalışılmıştır. Bkz.; Türkkan, a.g.m., s. 51.

78 Özemre, a.g.e., s. 34. "Radyasyon bulutunun Edirne ve civarını etkisi altına almış olduğunun tespit edilmiş olduğu, paniğe kapılmak için tehlikeli bir durumun mevcut olmamakla birlikte" ikinci bir bildiriye kadar bazı tavsiyelerde bulunulmuştur: Mümkün olduğu kadar yağmur altında kalınmaması, çamurlanan ayakkabı ve elbiselerin sürekli akan bir suyun altına tutularak temizlenmesi, sebze ve meyvelerin akan suyun altında uzun süre yıkandıktan sonra yenilmesi, büyükbaş hayvanların ahırlarda karantina altında tutulması tavsiye edilmiștir. a.g.e., s. 32 .

79 TAEK, no. 5, s. 31.

80 Özemre, a.g.e., s. 288.

81 Özemre, radyasyon düzeylerinin halka açıklanmasını bir nükleer kazada en yapılmaması gereken şey olarak nitelendirmekte ve 1957 yılında İngiltere'nin kuzeyinde Windscale nükleer santralindeki kaza sonrasında her gün ölçülen radyasyon değerlerinin İngiliz Atom Enerjisi Kurumu tarafından halka açıklanmasının olumsuz etkilerinden söz etmektedir. Radyasyon düzeylerinin ne anlam ifade ettiğinin işin uzmanı kişiler dışında yorumlanamayacağının ve radyasyon düzeylerinin kamuya açıklanmasının halkın paniğe kapılmasına yol açacağının altını çizmekte ve bununla ilgili de Çernobil kazası sonrasında radyasyon düzeyini günü gününe halka açıklayan ülkelerden çeşitli örnekler vermektedir. a.g.e., s. 45-46. 
ilgili kamuoyu bilgilendirilmesi konusunda TAEK başkanı Özemre ve Sanayi ve Ticaret Bakanı Cahit Aral'ın resmi yetkili konumunda olduğu görülmektedir.82

Özemre'nin belirttiği gibi radyasyon konusunda Türkiye'de o dönemde 2690 sayılı kanun ${ }^{83}$ gereği tek yetkili kurum TAEK'tir. ${ }^{84}$ Özemre, Çernobil kazası sonrasında alınması gereken önlemlerin TAEK'in yetki sınırlarını aştığını ifade etmektedir. Örneğin TAEK'in gümrüklerdeki ithal ve ihraç edilecek mallarda radyasyon ölçümü yapıp gönderim ya da alım durumlarına karar yetkisi yoktu. Bu ve benzeri konularda yetki tıkanıklıklarının aşılması amacıyla ve ilgili birimler arasında koordinasyonu sağlayacak bir organizasyonun gerekli görülmüştür. Dışişleri Bakanlığı'nın tavsiye yazısına dayanarak Başbakan'ın emriyle 26 Mayıs 1986'da Çernobil kazasının Türkiye'deki etkilerini, ilgili ve yetkili kuruluşların koordinasyonuyla çözümlemeye yönelik olarak Türkiye Radyasyon Güvenliği Komitesi kurulmuştur. 85 Meclis Araştırması Komisyon Raporu'nda belirtildiği üzere bu komite kazanın ekonomik ve siyasal boyutlar kazanması nedeniyle kurulmuştur. Silahlı Kuvvetler, mülki amirlikler ve ilgili bakanlıklar ile işbirliği sağlanmıştır. Ancak mevcut teknik eleman ve cihaz potansiyelinin yetersizliği nedeniyle radyoaktif kirlenme düzeylerinin belirlenmesi ve ölçülmesinde yetersizlikler olmuştur. ${ }^{86}$

82 Kaza sonrasında Türkiye kamuoyunda radyasyondan etkilenmiş Karadeniz bölgesinde üretilen çayların iç piyasaya sürüldüğü ve bunun kamu sağlığı açısından zararlı olduğu iddialarına karşın resmi yetkililerin bu algının ve korkunun yersiz olduğunu göstermek için ciddi çaba harcadığı görülmektedir. Sanayi ve Ticaret Bakanı Cahit Aral'ın basın önünde çay içerek algıyı değiştirmeye çalışması bu yöndeki çabalardan biridir. Ayrıca Özemre, kitabında basının kamuoyunu yanlış yönlendiren haberlerden dolayı yaşamış olduğu zorluğu ayrıntılarıyla anlatmaktadır. Bu konuda bkz.; Özemre, a.g.e. "Çaycı Bakan”, Milliyet, 09 Aralık 1986, s.7.

83 İlgili kanun için bkz. http://www.mevzuat.gov.tr/MevzuatMetin/1.5.2690.pdf 84 Özemre, "Türkiye Atom Enerjisi Kurumu Kanunu", 1985 tarihli “Radyasyon Güvenliği Tüzüğü" ile Çernobil kazası meydana geldiğinde her ikisi de geçerli olan 1968 ve 1975 tarihli "Radyasyon Sağlığı Yönetmeliği" tetkik edildiğinde, ülkenin radyasyon sağlığı ve güvenliği temin görevinin bilimsel sorumluluğunun ve yetkisinin yalnızca TAEK'e ait olduğunu ve kurumun ekonomik-siyasi yetki ve sorumluluğunun olmadığını belirtmektedir. Özemre, a.g.e., s. 278. Özemre'nin 21 Şubat 1993 tarihinde TBMM'ne Çernobil kazası ile ilgili yaptığı açıklamanın tam metni için bkz. a.g.e., ss. 269-320.

85 Greenpeace'in 26 Nisan 1996 tarihli raporunda belirtildiği üzere, 14 Mayıs 1986'da Dışişleri Bakanı Vahit Halefoğlu Başbakanlığa yazdığı "Gizli” damgalı mektupla Türkiye Radyasyon Güvenliği Komitesi'nin kurulmasını istemiștir. Bu mektupta Doğu Bloğu ülkelerinden gıda maddeleri ithalatı üzerine 31 Mayıs 1986'ya kadar geçerli AET yasağından da söz edilmektedir. Greenpeace Raporu, Nisan 1996, http://www. greenpeace.org/turkey/Global/turkey/report/2012/04/cernobilin-turkiyeuzerindeki-etkileri.pdf (Erişim Tarihi 15 Aralık 2015).

${ }^{86}$ Meclis Araștırması Komisyonu Raporu, https://www.tbmm.gov.tr/sirasayi/donem19 _yil01/ss455.pdf,90. 15.02.1994 tarihli T.B.M.M Tutanak Dergisi'nde yer alan (10/77, 78, 82, 84) esas numaralı meclis araştırması komisyonu raporu. Çernobil kazasından 7 yll sonra özellikle Doğu Karadeniz'de yaşayanlarda Çernobil'le bağlantılı kanser iddialarıyla ilgili tartışmalar üzerine "Çernobil faciasının verdiği zararların tespiti ve

Sayfa/Page | 167

IGU J. Soc. Sci., 4 (1), 2017, pp. 151-179. 
Sayfa/Page | 168

İGÜ Sos. Bil. Derg., 4 (1), 2017, ss. $151-179$

\section{Kriz Yönetim Sürecine Geçiş}

Acil durumun yönetilemediği ya da yetersiz kaldığı durumlarda kriz yönetimi başlamaktadır. Komitenin kurulması amacı bağlamında, Türkiye Radyasyon Güvenliği Komitesi'nin kurulmasıyla birlikte acil durum yönetiminden kriz yönetimine geçilmiştir. Özemre'nin ifadesiyle "olağan dışı bir kriz komitesi" olan Türkiye Radyasyon Güvenliği Komitesi'nin başkanı Sanayi ve Ticaret Bakanı Cahit Aral'dır. Komitede Başbakanlık, Dışişleri Bakanlığı, Sağlık ve Sosyal Yardım Bakanlığı, Tarım, Orman ve Köyişleri Bakanlığı, Sanayi ve Ticaret Bakanlığı, Kültür ve Turizm Bakanlığı'nın yanında TAEK'in, Hazine ve Dış Ticaret Müsteşarlığı'nın, Çevre Genel Müdürlügü̈nün ve İTÜ'nün yüksek kademe görevlileri bulunmuştur. ${ }^{87}$ Komitenin hedefleri; Çernobil'in radyoaktif etkilerini düzenli ölçümlerle yakından incelemek, ölçüm sonuçlarını iç ve dış kamuoyuna duyurmak, radyasyon güvenliği konusunda alınması gereken kısa ve uzun vadeli tedbirleri tespit etmek ve Türkiye'nin ihracatı ve turizmi üzerinde olumsuz sonuçlara yol açabilecek izlenimlerin bertaraf edilmesi olarak belirtilmektedir. 88

Türkiye'de Çernobil kazasının yaşandığı dönemde bir radyasyon erken uyarı sistemi ağı bulunmuyordu. Özemre bundan dolayı radyasyon vurgununu anında tespit etme imkânının olmadığını belirtmektedir. Radyasyonun varlığı ancak bölgeye gidip ölçüm yapılarak sonradan tespit edilebilmektedir.89 Dolayısıyla Çernobil kazasının yaşandı̆̆ı dönemde Türkiye'de olası bir radyoaktif kirlenme halinde anında devreye girmeye hazır bir uyarı ve önlem mekanizması olmadığı görülmektedir. 29 Mayıs 1986'da Türkiye Radyasyon Güvenliği Komitesi'nin ilk toplantısında, "Önlem ve Tehlike Durum Planı" hazırlanması konusunda TAEK'in görevlendirilmesi kararlaştırılmıştır. Türkiye Radyasyon Güvenliği Komitesi'nin 3 Temmuz 1986'daki ikinci toplantısında ise radyasyon erken uyarı sistemlerinin kurulmasına karar verilmiştir. ${ }^{90}$

Türkiye Radyasyon Güvenliği Komitesi'nin 29 Mayıs 1986'da yapılan ilk toplantısında Türkiye'de her türlü gıda maddesinin radyasyon sağlığı bakımından bir sakıncası bulunmadığının tespit edildiği bildirilmiştir.

giderilmesi için alınacak önlemleri belirlemek amacıyla" T.B.M.M genel kurulunun 19.01.1993 tarihli 56. birleşiminde Meclis Araştırması Komisyonu kurulmuştur.

87 Özemre, a.g.e., s. 66.

${ }^{88}$ Greenpeace Raporu, Nisan 1996, http://www.greenpeace.org/turkey/Global/turkey /report/2012/04/cernobilin-turkiye-uzerindeki-etkileri.pdf (15 Aralık 2015).

89 Özemre, a.g.e., s. 60.

${ }_{90}$ Meclis Araştırması Komisyonu Raporu, https://www.tbmm.gov.tr/sirasayi/donem

19/yil01/ss455.pdf, s. 94. RESA hakkında bilgi için bkz. http://www.taek.gov.tr/

radyasyon-izleme/radyasyon-erken-uyari-sistemi-agi-resa.html 
Toplantıda Türkiye'de radyasyon seviyesinin doğal seviyede olduğuna dair Türkiye Radyasyon Güvenliği Komitesi başkanlığg tarafından iç ve dış kamuoyuna açıklama yapılması kararlaştırılmıştır.91 Türkiye'de ülkenin büyük bir kısmının Çernobil kazasından hemen hemen hiç etkilenmediği ya da kayda değer bir kirlenme yaşanmadığ kabul edilmiştir.92 Komitenin 3 Temmuz 1986'daki ikinci toplantısında SSCB'nin atmosfere ve yeraltına sızan radyasyonun önüne geçildiği dair açıklamaları değerlendirilmiştir. Ayrıca çeşitli uluslararası kuruluşların bu gibi olayların önlenmesi için çalışmalar başlattığı bildirilmiştir. ${ }^{93}$ Komitenin her iki toplantısındaki gündem maddeleri ve alınan kararlar incelendiğinde; Çernobil kazası sonucunda ortaya çıkan radyoaktif kirlilikten etkilenen Türkiye'de, radyasyon düzeylerinin normal değerlere indiği ve insan sağlığı ve çevre açısından sakıncalı bir durumun olmadığının tespit edildiği görülmektedir. Komite toplantılarında durum tespiti yapılması, ölçüm sonuçlarının analiz edilmesi ve tehlike durumunun söz konusu olmadığına kanaat getirilmesi, bunun yanında kazanın kontrol altına alındığına dair SSCB'den gelen açıklamalar krizin yumuşama evresini oluşturmaktadır.

\section{Çernobil Kazasının Türk Dış Politikasına Yansıması}

30 Nisan 1986'da SSCB büyükelçisi Dışişleri Bakanlığı'na Çernobil kazası ile ilgili bilgi vermiştir.94 Dünya Sağlık Örgütü Türkiye'nin 29-30 Nisan 1986'da radyasyon bulutu etkisi altına girdiğini saptamıştır. Çalışma ekseninde yapılan araştırmalarda Türkiye'nin Çernobil kazası dolayısıyla SSCB'ye nota verildiği bilgisiyle karşılaşılmamıștır.

9 Mayıs 1986'dan itibaren Dışişleri Bakanlığı aracılığıyla çeşitli büyükelçilikler Türkiye'den radyasyon düzeyleri ile ilgili düzenli bilgi istemeye başlamıştır. Özemre'nin belirttiği üzere "karşılık esasına dayalı olmak üzere” bu bilgiler kendilerine verilmiştir. Türkiye bu şekilde diğer ülkelerdeki radyasyon düzeyleri hakkında bilgi sahibi olmuştur. Dolayısıyla Türkiye'nin Çernobil kazasından etkilenen ülkelerden de doğrudan bilgi talebinde bulunmadığı söylenebilir. Türkiye ayrıca üyesi olduğu Uluslararası

\footnotetext{
91 a.g.r., s. 16-17.

92 Özyar, a.g.m.

93 a.g.r., s. 18.

94 Başbakanlık Basın Yayın Enformasyon Genel Müdürlügü'nün verilerinde 30 Nisan 1986'da SSCB'nin Ankara Büyükelçisi Vladimir Lavrov'un Dışişleri Bakanlığı Siyasi İşlerden Sorumlu Müsteşar Yardımcısı Ecmel Barutçu'yu ziyaret ederek, Çernobil'de meydana gelen kaza ve radyasyon sızıntısı nedeniyle ortaya çıkan tehlike hakkında bilgi verdiği ve Türkiye'nin Karadeniz sahillerinde radyasyon ölçümü yapmasını ve alınan sonuçların kendilerine iletilmesini istediği bildirildiği belirtilmektedir. http://ayintarihi.byegm.gov.tr/turkce/date/1986-04-30 (Erişim Tarihi 15 Aralık 2015).
}

Sayfa/Page | 169

IGU J. Soc. Sci., 4 (1), 2017, pp. 151-179. 
Sayfa/Page | 170

İGÜ Sos. Bil. Derg., 4 (1), 2017, ss. $151-179$

Atom Enerjisi Ajansı'na ve Ekonomik İşbirliği ve Kalkınma Örgütü (OECD) Nükleer Enerji Ajansı'na da radyasyon düzeylerini bildirmiştir. 95

Türkiye'nin Çernobil kazasının ekonomik yansımalarına karşı stratejiler geliştirdiği görülmektedir. Özellikle stratejik malların üretim alanlarının radyoaktif kirlilikten etkilenmesinden dolayı bu ürünlerin diğer ülkelere ihracı konusunda sorunlar yaşanmıştır. Ticari öneme sahip tarımsal ürünlerle ilgili konularda radyasyonlu çay krizi, fındık krizi gibi vb. şeklinde "kriz" nitelemesini kullanılmıştır.96 Radyasyondan etkilenen bölgelerdeki tarımsal ürünler konusunda hem Türkiye için de hem de bunların diğer ülkelere ihracı boyutlarıyla ekonomik anlamda krize neden olduğu görülmektedir. Çernobil kazasının ekonomik boyutu daha çok ticari ilişkiler içinde olunan ülkelerin ithal edecekleri tarımsal ürünlerde radyasyon sınırı belirlemeleri şeklinde görülmektedir. Bu süreç içerisinde belirlenen radyasyon sınırının ülkeden ülkeye değiştiği97 ve her ülkeye aynı sınırın uygulanmadığından bahsedilmektedir. Örneğin, Avrupa Ekonomik Topluluğu Türkiye'den alacağı gıda maddeleri için $600 \mathrm{~Bq} / \mathrm{kg}^{\prime}$ 'lik radyasyon sınırını kabul ederken, üyeleri arasındaki ithalatta bu değeri $1200 \mathrm{~Bq} / \mathrm{kg}$ olarak belirlemiştir.98 Türkiye Radyasyon Güvenliği Komitesi'nin ilk toplantısında gida maddelerinin ithalatında AET'nin belirlediği radyasyon sınırının altındaki gıda maddelerinin ithalatına izin verilmesi ve ihracatçıların da "Radyasyondan Aridir" belgesi almadan ihracat yapmamaları karara bağlanmıştır. 99

AET 30 Mayıs 1986 gün ve 1707 sayılı kararı ile 1 kg'da 600 bekerelin üzerinde radyasyon taşıyan gıda maddelerinin kullanımını ve ticaretini yasaklamıştır. Türkiye 9 Temmuz 1986'da dış ülkelere 600 bekerel radyasyon sınırına uyacağı güvencesini vermiștir. 9 Mayıs 1986'da Suudi Arabistan, 14 Mayıs 1986'da da Avusturya aşırı radyasyon nedeniyle Türkiye'den gıda alımını durdurmuştur. 23 Kasım 1986'da Almanya'ya ihraç edilmiş olan 40 ton fındık 1264 bekerel radyasyon içerdiği gerekçesiyle iade edilmiştir. 29 Kasım 1986'da Hollanda sağlık bakanı Türk çayında 35000 bekerel radyasyon olduğunu resmen bildirmiștir. 13 Aralık'ta KKTC, 18 Aralık'ta Batı Almanya ve İsviçre Türkiye'den çay, fındık ve tütün ithalatını yasaklamıştır.100 Yapılan ölçümler sonucunda $12500 \mathrm{~Bq} / \mathrm{kg}^{\prime}$ lik limiti aştığı saptanan çay, ÇAYKUR'a ait

95 Özemre, a.g.e., s. 46.

96 a.g.e.

97 Türkiye Radyasyon Güvenliği Komitesi'nin ikinci toplantısında yaptığı açıklamada Özemre; insan sağlı̆ına zarar vermeyen radyoaktivite limitlerinin belirlenmesinde dünyada belli bir standardın olmadığı ve Dünya Sağlık Örgütü, Uluslararası Atom Enerjisi Ajansı ve AET'in birbirinden farklı standartları kullandığını belirtmiştir. A.g.r., S. 18.

98 Türkkan, a.g.m., s. 55-56.

99 Özemre, a.g.e., s. 75.

100 a.g.r, s. 1. 
depolarda muhafaza edilmiş daha sonra gömülerek imha edilmiştir.101 7 Haziran 1986'da Bahreyn Çernobil kazasını gerekçe göstererek aralarında Türkiye'nin de bulunduğu bazı ülkelerden gıda ürünleri ithalatını durdurmuş̧tur. ${ }^{102} 10$ Kasım 1986'da İngiltere Sağlık Bakanlığı AET standartlarının çok üzerinde radyasyon taşıdığı gerekçesiyle Türkiye'den gelen 40 ton fındığa giriş yasağı koymuştur. ${ }^{103}$

Kriz sonrası evrede 19 Ocak 1993 tarihinde "Çernobil faciasının verdiği zararların tespiti ve giderilmesi için alınacak önlemleri belirlemek" amacıyla kurulan Meclis Araştırması Komisyonu çalışmalarında Çernobil'in Türkiye üzerindeki etkileri yeniden gözden geçirilmiştir. Uluslararası düzeyde ise alınan ortak önlemler, yeni korunak binası yapımının sağlanması gibi ortak fonlar, kriz dönemindeki zarar/ziyanın nasıl karşılanacağı gibi konular gündeme gelmiştir. Kaynak ülkeden mi tazminat talep edileceği yoksa ülkelerin kendi fonlarını ${ }^{104} \mathrm{mı}$ kullanacakları tartışılmıştır. Kazadan etkilenen bazı ülkelerin tazminat arayışları söz konusu olmuştur. Çernobil krizinin dış politika/uluslararası kriz boyutu dikkate alındığında devletten devlete işlemesi gereken bir süreci ortaya çıkartmaktadır. Türkiye, nükleer serpinti sonucu uğramış olduğu zarar/ziyanın tazmini konusunu SSCB'den istemekte sessiz kalmıştır. Federal Almanya ${ }^{105}$ ve Avusturya SSCB'den zararlarının tazminini talep etme girişimlerinde bulunmuşlardır. İsveç ve İngiltere ${ }^{106}$ gibi ülkelerde de SSCB'den tazminat talebi konusu tartışılmıştır. Ancak Çernobil kazasının diğer ülkelerde sebep olduğu zarar/ziyanın tazmini konusuna dayanak oluşturacak herhangi bir sözleşmeye SSCB'nin taraf olmamasından dolayı1 ${ }^{107}$ sonuç alınamamıştır.

101 Türkkan, a.g.m, s. 51.

102 http://ayintarihi.byegm.gov.tr/turkce/date/1986-06-7 (Erișim Tarihi 15 Aralık 2015).

${ }^{103}$ http://ayintarihi.byegm.gov.tr/turkce/date/1986-11-10 (Erișim Tarihi 15 Aralık 2015).

${ }^{104}$ Batı Almanya ulusal yasal düzenlemelerinin sorumluluğu dahilinde süt üreticileri, çiftçiler ve avcıların tazminat taleplerini kendi fonlarıyla ödemiştir. Werner Eich, "The Compensation of Damage in Germany Following the Chernobyl Accident",

Indemnification of Damage in the Event of a Nuclear Accident, Workshop Proceedings Paris, France 26-28 November 2001, s. 89-99.

105 Batı Almanya Başbakanı Helmut Kohl, ülkesi üzerinde Çernobil felaketinin sebep olduğu zararların SSCB'den tazmini konusunu gündeme getirmiștir. SSCB'nin resmi haber ajansı TASS Kohl'un iddiasını "tamamen dayanaksız" olarak nitelendirmiștir.

"Readers Offer Help to Chernobyl Victims", Observer-Reporter, 19 Mayıs 1986. https://news.google.com/newspapers?id=9yxiAAAAIBAJ\&sjid=vnYNAAAAIBAJ\&pg=1 126\%2C2434306 (Erişim Tarihi 09 Nisan 2016).

106 Lee Stokes, "Britain may Press for Chernobyl Compensation", United Press International, 30 Haziran 1986. http://www.upi.com/Archives/1986/06/30/Britainmay-press-for-Chernobyl-compensation/5060520488000/ (Erişim Tarihi 09 Nisan 2016).

${ }^{107}$ Kazanın meydana geldiği dönemde nükleer sorumluluk konusunda var olan üç uluslararası sözleşmenin (1960 tarihli Paris Sözleşmesi, 1963 tarihli Viyana ve

Sayfa/Page | 171

IGU J. Soc. Sci., 4 (1), 2017, pp. 151-179. 
Tablo 1: Çernobil Krizine Dair Kronoloji

Sayfa/Page | 172

İGÜ Sos. Bil. Derg.,

4 (1), 2017,

ss. 151-179.

\section{KRONOLOJI}

Kriz Evresi

- Kazanın Meydana

Gelmesi

- Kontrol

Programının

Başlatılması

- Koordinasyon

Komitesinin

Kurulması
26 Nisan 1986: Çernobil Nükleer Santrali'nin dördüncü ünitesinde kaza meydana gelmiștir.

28 Nisan 1986: İsveç'te bulunan Forsmark nükleer santralindeki rutin radyasyon kontrollerinde tespit edilen radyasyon kirliğinin kaynağının Çernobil nükleer santrali olduğu açıklanmıştır.

29 Nisan 1986: Türkiye'de son TV haberlerinde Kiev yakınlarında bulunan Çernobil nükleer santralinin dört numaralı reaktör ünitesinde üç gün önce büyük bir nükleer kaza meydana gelmiş olduğu bildirilmiştir. TAEK teyakkuz durumuna geçirilmiştir.

30 Nisan 1986: TAEK tarafından radyasyon ölçüm programı başlatılmıştır.

30 Nisan 1986: SSCB büyükelçisi Dışişleri Bakanlığı'na Çernobil kazası ile ilgili bilgi vermiştir.

30 Nisan 1986: Çernobil nükleer santralindeki kaza haberi gazetelerde yer almıştır.

30 Nisan 1986: TAEK başkanı Ahmed Yüksel Özemre İstanbul'da basın toplantısı düzenlemiștir.

30 Nisan 1986: ÇNAEM'de yapılan ölçümlerde yükseklik tespit edilmiștir.

3 Mayıs 1986: Radyoaktif bulut Bulgaristan ve Yunanistan üzerinden Trakya Bölgesi'ne ulaşmıştır.

3 Mayıs 1986: TAEK'in Çernobil kazasıyla ilgili resmi bildirisi radyo ve televizyondan yayınlanmıştır.

7 Mayıs 1986: Radyoaktif serpintiden Doğu Karadeniz bölgesi etkilenmiştir.

9 Mayıs 1986: Dışişleri Bakanlığı aracılı̆̆ıyla çeşitli büyükelçilikler Türkiye'den radyasyon düzeyleri ile ilgili düzenli bilgi istemeye bașlamıștır.

Brüksel Sözleşmesi) hiç birine SSCB taraf değildir. Stern, a.g.e., s. 150, 249-250.

Richard E. Levy, "International Law and the Chernobyl Accident: Reflections on An Important but Imperfect System", Kansas Law Review, Cilt 36, sayı 8, 1987, s. 90-96.

Schwartz, a.g.m., s. 38. 


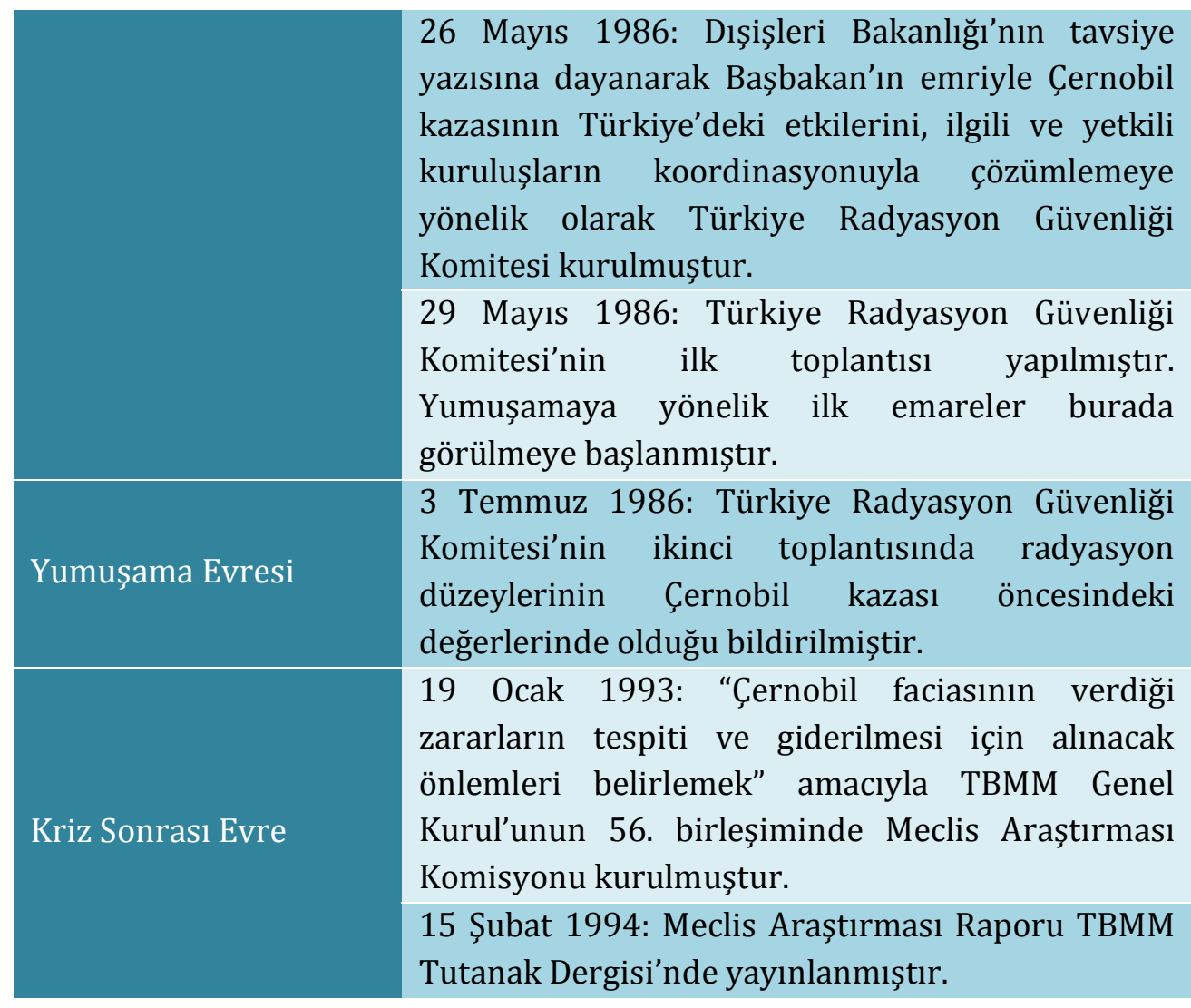

Sayfa/Page | 173

IGU J. Soc. Sci.,

4 (1), 2017,

pp. 151-179.

Çernobil kazası o dönemde mevcut nükleer sorumluluk rejiminin ne kadar eksik olduğunu göstermiş ve kaza sonrasında kazanın gerçekleștiği ülkeyle sınırlı olmaksızın nükleer kaza mağdurlarının zarar/ziyanının tazmini ve sınır aşan çevresel zararların sorumluluğu ile ilgili uluslararası düzenleme yapılması gündeme gelmiştir. Birçok ülke ulusal tazminat rejimlerinin yanında sınır ötesi etkileri olan bir nükleer kazadan tazminat talebini sağlamak üzere, sorumluluk ve tazminat rejimlerini tesis eden çeşitli uluslararası sözleşmelere taraf olmuştur. ${ }^{108}$

Çernobil kazasından sonraki süreçte böylesi bir kaza durumunda Çernobil deneyiminde yaşanan sorunların yaşanmaması adına uluslararası çabalar söz konusu olmuş ${ }^{109}$ ve Türkiye de bir takım uluslararası sözleşmelere taraf olmuştur. Çernobil kazasını takiben kabul edilen sözleşmeler "Nükleer Kaza Halinde Erken Bildirim Sözleşmesi"110, "Nükleer Kaza ve Radyolojik Acil

\footnotetext{
108 http://www.taek.gov.tr/nukleer-guvenlik/nukleer-enerji-ve-reaktorler/166gunumuzde-nukleer-enerji-rapor/442-bolum-08-uluslararasi-nukleer-duzenlemelerve-nukleer-silahlarin-yayilmasinin-onlenmesi.html (Erişim Tarihi 10 Nisan 2016). 109 Levy, a.g.m., s. 81-82.

${ }^{110}$ Sözleşme metni için bkz. http://www.taek.gov.tr/attachments/article/769/137 _erken_bildirim_tr.pdf (Erişim Tarihi 06 Nisan 2016).
} 
Hallerde Yardımlașma Sözleşmesi"111 ve "Nükleer Enerji Alanında Üçüncü Şahıslara Karşı Hukuki Sorumluluğa İlişkin Paris Sözleşmesi'ni Yenileyen 1982 Ek Protokolü"112 dür.

\section{SONUÇ}

Çernobil kazasının dünya gündemine oturması yol açtığı felaketin büyüklüğünden ve radyoaktif serpintinin etkilediği alanın genişliğinden kaynaklanmıştır. Bu tür kazalarda radyasyon yayılımı ülke sınırlarından bağımsızdır. Çernobil kazası ile nükleer radyoaktif yayılımın sınır tanımazlığı görülmüştür. $\mathrm{Bu}$ bağlamda Çernobil kazası "ulusal sınırları aşan nükleer felaket"113 olarak adlandırılmaktadır. Kaza sonrası oluşan nükleer serpintinin birincil etkisi can güvenliği ve sağlık üzerine olan etkisidir. Dolayısıyla ulusaluluslararası düzlemde acil durum yönetimi gerekmiştir. İlerleyen süreçte ise çevrenin kirlenmesi ve özellikle tarımsal ürünlerin serpinti sonucunda zarar görmesi ekonomik ve ticari kayıplara neden olmuștur.

Çernobil kazası sonuçları ve etki alanı göz önüne alındığında aslında uluslararası bir krizdir, nitekim kazadan etkilenen bazı Avrupa ülkeleri tarafından çevresel, siyasal ve ekonomik bir kriz olarak ele alınmıştır. Bu bağlamda Çernobil kazası, kazadan etkilenen ülkelerde sağlık ve çevresel sorunların yanı sıra kriz yönetimine ilişkin sorunları da gündeme getirmiştir. Bunun yanında Çernobil kazası yalnızca SSCB'nin değil, kazadan etkilenen pek çok ülkenin de kendi sınırları dışında meydana gelebilecek bir nükleer kazanın etkilerini azaltacak önlemleri almakta yetersiz kaldıklarını ortaya çıkarmıștır.114

Sovyet hükümeti kazanın üzerinden yaklaşık 64 saat geçtikten sonra kazayı kabul etmiştir. Sovyetlerin kazayla ilgili daha fazla bilgi vermemesi ülkelerin kriz yönetimini engellemiştir.115 Kazanın duyulmasıyla birlikte özellikle nükleer serpintiden etkilenen/etkilenecek ülkelerde medya, siyasi liderler ve vatandaşlar büyük bir endişeye kapılmışlardır. Çernobil'de tam olarak ne olduğuna dair SSCB'nin dünyayı bilgilendirmemesi, sessiz kalması ve kaza hakkında ayrıntıları paylaşmaması yoğun bir şekilde eleştirilmiştir. ${ }^{116}$

${ }^{111}$ Sözleşme metni için bkz. http://www.taek.gov.tr/attachments/article/770/136 kaza yardimlasma tr.pdf (Erişim Tarihi 06 Nisan 2016).

112 Sözleşme metni için bkz. http://www.taek.gov.tr/attachments/article/762/907 paris 1982 tr.pdf (Erişim Tarihi 06 Nisan 2016).

${ }^{113}$ Chernousenko, a.g.e.

114 TAEK, no. 5.

115 Otway, a.g.m., s. 135.

116 Mara, a.g.e., s. 54. Bohlen, a.g.m., s. 38. 
Türkiye'de Çernobil nükleer santralindeki kaza sonucunda oluşan nükleer serpintiden etkilenen ülkeler arasındadır. Acil durum yönetimi süreci TAEK tarafından yürütülmüştür. Süreç içerisinde kazanın sonuçlarının farklı boyutlar kazanmasıyla birlikte, Türkiye kazanın etkileriyle baş etmek üzere stratejilere ihtiyaç duymuștur. Bunun sonucunda ilgili birimler arasında koordinasyonu sağlamak için ad hoc nitelikte bir kriz komitesi olarak Türkiye Radyasyon Güvenliği Komitesi kurulmuş ve acil durum yönetiminden kriz yönetimine geçiş söz konusu olmuştur.

Soğuk Savaş'ın sürdüğü bir tarihsel kesitte ve Türkiye ile SSCB arasındaki ekonomik ilişkilerin geliştiği bir ortamda meydana gelen Çernobil kazası, Türkiye tarafından resmi düzeyde SSCB'nin sorumlu tutulduğu bir olay olarak ele alınmamıştır. Çernobil Türkiye ve SSCB arasındaki ikili ilişkilerde bir kırılmaya neden olmamıștır. Çernobil kazası Türk dış politikasına siyasal bir kriz olarak yansımamıştır. Kazanın ekonomik sonuçlarıyla baş etme yönündeki politikalardan hareketle ekonomik bir kriz olarak algılandığı görülmektedir. Çernobil kazasından sonra böylesi bir kaza durumunda Çernobil deneyiminde yaşanan sorunların yaşanmaması adına bir takım uluslararası çabalar söz konusu olmuştur ve Türkiye'de bu sürece dahil olmuştur.

\section{KAYNAKÇA}

ARPAT, Recep Sait, Acil Durum ve Kriz Yönetimi: NATO, AB, ABD, Birleşik Krallık Analizleri ve Türkiye Modeli, Ankara: Gece Kitaplığı, 2016. BOHLEN, Celestine, "Soviet Secrecy in the Face of Calamity", ed. David Erik Nelson, Perspectives on Modern World History: Chernobyl.

Farmington Hills, Greenhaven Press, 2009: 36-42.

BRECHER, Michael, Crisis in World Politics: Theory and Reality. Oxford: Pergamon Press, 1993.

CHERNOUSENKO, Vladimir M., Chernobyl: Insight from the Inside. çev. John G. Hine, Springer-Verlag Berlin Heidelberg, 1991.

ÇAKMAK, Haydar, Uluslararası Krizler ve Türk Silahlı Kuvvetleri. Ankara: Platin, 2004.

ÇİMEN, Ali, Tarihi Değiştiren Günler. 3. bs. İstanbul: Timaş Yayınları, 2013.

Ekonomi ve Dış Politika Araştırmalar Merkezi, Nükleer Enerjiye Geçişte Türkiye Modeli, ed. Sinan Ülgen. İstanbul, 2011. 
Sayfa/Page | 176

İGÜ Sos. Bil. Derg., 4 (1), 2017, Ss. $151-179$.

EICH, Werner. "The Compensation of Damage in Germany Following the Chernobyl Accident", Indemnification of Damage in the Event of a Nuclear Accident, Workshop Proceedings Paris, France 26-28 November 2001: 8999.

GUSTAFFSON, Lena, "Environmental Crisis as Drivers of the State and Use of Swedish Forests". External Drivers Affecting Swedish Forest and Forestry. Future Forest Working Report. 2009.

Greenpeace Raporu. http://www.greenpeace.org/turkey/Global/ turkey/report/2012/04/cernobilin-turkiye-uzerindeki-etkileri.pdf (Erișim Tarihi 15 Aralık 2015).

KAPLAN, Steven G., "Compensating Damage Arising From Global Nuclear Accidents: The Chernobyl Situation". Loyala of Los Angales International and Comparative Law Review. Cilt 10. No 1. (1988): 241-269. http:// digitalcommons.lmu.edu/cgi/viewcontent.cgi?article=1133\&context=ilr (Erişim Tarihi 08 Nisan 2016).

LEVY, Richard E., "International Law And The Chernobyl Accident: Reflections On An Important But Imperfect System". Kansas Law Review. Cilt 36. No 8. (1987): 81-131. https://kuscholarworks.ku.edu/handle/1808/1004 (Erişim Tarihi 08 Nisan 2016).

MARA, Wil, The Chernobyl Disaster: Legacy and Impact on the Future of Nuclear Energy. New York: Marshall Cavendish, 2011.

MAZLUM, İbrahim, "Küresel Siyaset ve Çevre". Küresel Siyasete Giriş: Uluslararası İliş̧kilerde Kavramlar, Teoriler, Süreçler. Der. Evren Balta. İstanbul: İletişim Yayınları, 2014.

Meclis Araștırması Komisyonu Raporu, https://www.tbmm.gov.tr/ sirasayi/donem19/yil01/ss455.pdf. (Erişim Tarihi 24 Kasım 2015).

OTWAY, Harry, "The Media and Crisis Management", Chernobyl: A Policy Respond Study, ed. Boris Segerstahl, (Laxenburg: International Institute for Applied Systems Analysis, 1991): 133-146.

ÖZCAN KARA, Pelin, Emel Ceylan Günay. "Çernobil Kazası ve Etkileri”. M. Ü. Tıp Fakültesi Lokman Hekim Tıp Tarihi ve Folklorik Tıp Dergisi. s. 3. n. 2. (2013): 32-36.

ÖZEMRE, Ahmed Yüksel. Çernobil Komplosu. İstanbul: Bilge Yayıncılık, 2004

ÖZYAR, Enis, "Effects of Chernobyl”, http://link.springer.com/chapter/ 10.1007\%2F978-94-007-0975-1 13\#page-1. (Erişim Tarihi 24 Kasım 2015).

PALABIYIK, Hamit. Hikmet Yavaș, Murat Aydın. Türkiye'de Nükleer Santral Kurulabilir mi? Çatışmadan Uzlaşıya Nükleer Enerji ve Sosyal Kabul. Ankara: Uluslararası Stratejik Araştırmalar Kurumu, 2010.

Perspectives on Modern World History: Chernobyl. ed. David Erik Nelson. Farmington Hills, Greenhaven Press, 2009. 
SCHWARTZ, Julia A., "International Nuclear Third Party Liability Law: The Response to Chernobyl". International Nuclear Law in the PostChernobyl Period, OECD Nuclear Energy Agency, 2006: 37-72, https://www.oecd-nea.org/law/chernobyl/SCHWARTZ.pdf (04 Nisan 2016).

STERN, Eric K., Crisis Decisionmaking: A Cognitive Institutional Approach. Stockholm: Swedish National Defence College, 2003.

STOKES, Lee, "Britain may Press for Chernobyl Compensation". United Press International. 30 Haziran 1986. http://www.upi.com/Archives/1986 /06/30/Britain-may-press-for-Chernobyl-compensation/5060520488000/ (Erişim Tarihi 9 Nisan 2016).

TBMM Tutanak Dergisi, Dönem 17. Toplantı 99. c. 28. Nisan, 1986.

TELLAL, Erel, "SSCB'yle İlişkiler”. Türk Dış Politikası: Kurtuluş

Savaşından Bugüne Olgular, Belgeler, Yorumlar. c.2. 4. bs. ed. Baskın Oran. İstanbul: İletişim Yayınları, 2002. 158-166.

Türkiye Atom Enerjisi Kurumu, "Sağlık Bakanlığı Bilimsel Kurul Raporu ve Üniversite Görüşleri”. Çernobil Serisi. no. 2. 2. bs. Ankara, 2007.

Türkiye Atom Enerjisi Kurumu, "Çernobil Nükleer Santralinin Özellikleri ve Kazanın Oluşumu”. Çernobil Serisi. no. 4. 2. bs. Ankara, 2007.

Türkiye Atom Enerjisi Kurumu, "Çernobil Kazasının Ülkeler Üzerindeki Etkileri”. Çernobil Serisi. no. 5. 2. bs. Ankara, 2007.

Türkiye Atom Enerjisi Kurumu, "Türkiye'de Çernobil Sonrası Radyasyon ve Radyoaktivite Ölçümleri”. Çernobil Serisi, no. 6. Ankara, 2006.

TÜRKKAN, Alpaslan, “Çernobil Nükleer Santral Kazasının Türkiye’ye

Etkisi”. Çernobil Nükleer Kazası Sonrası Türkiye'de Kanser, Ankara: Türk Tabipleri Birliği Yayınları, 2006: 45-72.

VAROL SARAÇOĞLU, Gamze, "Son Yirmi Yılda Çernobil Kazası Sonrası Dünyada Yaşananlar”. Çernobil Nükleer Kazası Sonrası Türkiye'de Kanser, Ankara: Türk Tabipleri Birliği Yayınları, 2006: 11-43.

http://www.mfa.gov.tr/uluslararasi-cevre-konulari.tr.mfa (Erişim Tarihi 07 Aralık 2015).

http://teknolojikkazalar.org/show article/46485cb8ca2dd (Erişim Tarihi 13 Aralık 2015).

http://ayintarihi.byegm.gov.tr/turkce/date/1986-05-18 (Erişim Tarihi 13 Aralık 2015).

http://www.gecmisgazete.com/haber/tepemizde-olum-bulutudolasiyor (Erişim Tarihi 13 Aralık 2015).

http://fotoanaliz.hurriyet.com.tr/galeridetay/45429/4369/4/25-yilonceki-mansetler (Erişim Tarihi 13 Aralık 2015).

http://ayintarihi.byegm.gov.tr/turkce/date/1986-04-29. (Erişim Tarihi 13 Aralık 2015).

http://ayintarihi.byegm.gov.tr/turkce/date/1986-04-30. (Erişim Tarihi 15 Aralık 2015). 
Sayfa/Page | 178

İGÜ Sos. Bil. Derg., 4 (1), 2017, ss. $151-179$. http://ayintarihi.byegm.gov.tr/turkce/date/1986-06-7. (Erişim Tarihi 13 Aralık 2015).

http://ayintarihi.byegm.gov.tr/turkce/date/1986-11-10. (Erişim Tarihi 13 Aralık 2015).

“Çaycı Bakan”, Milliyet, 09 Aralık 1986, s. 7.

"Readers Offer Help to Chernobyl Victims", Observer-Reporter, 19 Mayıs 1986. https://news.google.com/newspapers?id=9yxiAAAAIBAI\&sjid =vnYNAAAAIBAI\&pg=1126\%2C2434306 (Erişim Tarihi 09 Nisan 2016).

"Chernobyl and Eastern Europe: One Year After the Accident", Radio

Free Europe Research. http://osaarchivum.org/files/holdings/300/8/3/pdf 669-7-122.pdf (Erişim Tarihi 01 Nisan 2016).

http://tdpkrizleri.org/index.php?option=com k2\&view=item\&id=229:k riz-c-karan-taraf-n-niyeti-veya-roluene-goere-tuerkiye-nin-d-s-politikakrizleri\&Itemid=103\&lang=tr(Erişim Tarihi 10 Nisan 2016).

http://tdpkrizleri.org/index.php?option=com seoglossary\&view=glossa ry\&catid=1\&id=17\&Itemid=111\&lang=tr $($ Erişim Tarihi 10 Nisan 2016).

http://www.mevzuat.gov.tr/MevzuatMetin/1.5.2690.pdf

http://www.taek.gov.tr/nukleer-guvenlik/nukleer-enerji-vereaktorler/166-gunumuzde-nukleer-enerji-rapor/442-bolum-08-uluslararasinukleer-duzenlemeler-ve-nukleer-silahlarin-yayilmasinin-onlenmesi.html (Erişim Tarihi 01 Nisan 2016).

http://news.bbc.co.uk/2/shared/spl/hi/guides/456900/456957/html/ nn3page1.stm (Erişim Tarihi 12 Mayıs 2016).

\section{Summary}

Accident occurred at the Chernobyl nuclear plant in Ukraine on 26 April 1986, has affected many countries in the northern hemisphere. In this study, the attitude of Turkey, one of the countries affected by the nuclear fallout, the emergency and crisis management processes it involved and the reflections on its foreign policy have been investigated.

The problems caused by the radioactive cloud formed as a result of accident, which moved to other countries through wind, and the search for solutions to these problems constitute an example of environment-foreign policy relations. The solution of problems faced after the Chernobyl accident required not only a national effort but an international cooperation, too. In this study, the overall political situation of the period, understanding of foreign policy, relations with the USSR and the occurence of the accident have been discussed. In addition, the effects of the Chernobyl accident with different dimensions and the 
measures taken have been concerned. Emergency and crisis management processes in Turkey after the Chernobyl accident have also been examined. The study also discusses, how the processes requiring emergency management at first turned into a foreign (economic) policy crisis. The study finds out that the environmental effects of nuclear fallout has led to economic problems, due to exposure to radioactive contamination of agricultural products and that the Chernobyl accident was not perceived as a political crisis in Turkish foreign policy. Instead, Turkey prefered to develop strategies against the economic repercussions of Chernobyl accident.

Sayfa/Page | 179

IGU J. Soc. Sci., 4 (1), 2017, pp. 151-179. 